\title{
Assessing Walkability in Sulaimani City Center
}

\author{
Roza Abdullatif Radha \\ City Planning Department \\ Technical College of Engineering \\ Sulaimani Polytechnic University \\ Sulaimani, Iraq \\ roza.radha@spu.edu.iq
}

\author{
Rozhen Kamal Mohammed-Amin \\ City Planning Department \\ Technical College of Engineering \\ Sulaimani Polytechnic University | Research Center \\ Sulaimani, Iraq \\ rozhen.mohammed@spu.edu.iq
}

Alan Faraydoon Ali

Presidency

Sulaimani Polytechnic University

Sulaimani, Iraq

alan.ali@spu.edu.iq

\begin{tabular}{|c|}
\hline Article Info \\
\hline $\begin{array}{l}\text { Volume 5-Issue 1-June } \\
2020\end{array}$ \\
\hline
\end{tabular}

Article history:

Received

Accepted

\section{Keywords:}

Walkability,

sidewalks, assessing walkability,

function, safety,

destination, aesthetic, comfort.

\begin{abstract}
Walkability within urban design and planning context refers to urban environments that are friendly and supportive for the pedestrian. Walkable environments offer many economic, social, health, and environmental benefits and contribute to UN Sustainable Development Goals (SDGs). In public places, including city centers, walkability is a major asset for making them vibrant by attracting and maintaining pedestrians, including tourists. It is no coincidence that the top tourist destinations and livable cities as well as popular city centers and streets all share walkability character.

Walkability quality in city center streets and any urban environment require planning. Good planning needs to be informed by measuring and assessing the state of walkability in existing streets and environments. While the literature presents systematic walkability assessment studies from different city centers of developed and developing countries, such studies are rare in the context of many other developing regions and countries like the Kurdistan Region and the rest of Iraq. Since walkability character can be contextual and affected by different socio-economic and environmental factors and dynamics, systematic and comprehensive assessment of under-researched environments and city centers are essential. To address this gap in the literature, this study systematically assesses the state of walkability in the city center of Sulaimani, the cultural capital of the Kurdistan Region of Iraq, and a UNESCO creative city in literature. This paper report results from assessing and comparing the physical characters of the six major interconnecting streets (Mawlawy, Kawa, Sabunkaran, Peramerd, Goran, and Bekas streets) in the center of Sulaimani city. The assessment considers the five main walkability factors of function, safety, destination, aesthetic, and comfort identified from the literature.
\end{abstract}




\section{INTRODUCTION}

Walkability is an important character in the built environment, including cities. It is one of the important aspects of New Urbanism since it improves the physical and mental health of pedestrians and can increase social interactions and economic opportunities [1], [2]. Walkability in city centers (CBD) is an important element for making the cities sustainable and livable cities due to their central role in urban development and city function [3]. Walkable city centers largely contribute to attracting local and international visitors and tourists. Pedestrian cities like Venice and Copenhagen are recognized for their livability and vibrancy, mainly due to the large pedestrian street network they have [1].

Walkable city centers refer to centers with large networks of car-free and accessible streets and public open spaces for people from different ages, groups, and physical abilities, including disabled [3]. Walkable city centers, where many essential buildings and services are located, promote compact urban development and use of public transportation [4]. In the last few decades, European city planners have taken different steps and measures to turn the streets of their city centers into pedestrian streets to support walkability and move away from relying on cars [5].

Unlike the sustainable re-development of European city centers, the re-developments of city centers in developing regions and countries like the Kurdistan Region and the rest of Iraq appear far from being pedestrian-friendly. Many of the walkable aspects of the old walkable city centers in these regions and countries are fading away in favor of car-oriented re-development [6]. Despite their vibrancy, the city center streets of cities like Sulaimani, the cultural capital of the Kurdistan Region of Iraq and a UNESCO Creative City of literature, are losing their walkable, social, and cultural characters to traffic and vehicles. In addition to lack of pedestrian-friendly development policies, regulations, and enforcement, lack of measurements and assessments for walkability levels in the city center further contribute to the fast transformation of the old city center of Sulaimani from walkable centers to one with high congestion. This study systematically measures, quantifies and assesses the state of walkability in six major connected streets in the city center of Sulaimani. Due to the quantity of collected and analyzed data through different methods and page limitations, this paper only reports results from physical measurements and assessment of those streets.

\subsection{What is walkability?}

\section{LITERATURE REVIEW}

Walking is part of everyday activities for many people from the minutes they wake up to the minute they sleep. We walk to and from our home, workplace, and recreational facilities/areas. Every trip starts and ends with some walking [7]. Walkability in urban space refers to space's ability to provide a comfortable, safe, and enjoyable walking experience for its pedestrians. Walkability, therefore, is related to the shape of the space where pedestrian walks in [8]. The walkability definition can vary according to means, outcomes, and proxies [9]. While some scholars consider walkable cities as those that are away from transportation [9], others consider it as cities that facilitate walking or using a bicycle instead of public transportation and private cars [10], [11], [12]. Some scholars define walkability in terms of land use density, street connectivity, diversity, and sidewalk access [8], while others define it in terms of physical attributes such as the width of street and sidewalk, building height, number of pedestrians, tree canopy, weather, and traffic volumes [7], [13].

Physical characters such as availability, quality, and usability of some physical elements affect walkability. Sidewalks width, height, ramps, and material, path and street design, and safety features (such as crossing, lighting, and anti-rigid and anti-slip floor) contribute to walkability 
of an environment at various levels [13], [14], and [15]. Walkability is also affected by the usability and maintenance of those elements [16], [17], and [18]. Walkable environments are often pleasant, attractive, clean, sociable, and lively [9]. [19], and [13]. Destination, represented in the availability and ease of access to public transport, the existence of shops and restaurants for pedestrians, as well as presence of protected bicycle lanes, is another component of walkable environments [13], [10], and [20].

\subsection{Why Walkability?}

Walkability provides health, environmental, social, and economic benefits [21], and that is why some scholars consider it "the foundation of the sustainable city". Walkable environments encourage active living for their pedestrians that reduce health problems and promote physical and mental well-being [22]. Physical inactivity from lack of walking can contribute to various diseases such as obesity, heart problems, and some types of cancer [23]. Some studies recommend 30 minutes daily walk, at least 5 days a week, for enjoying maintaining good health [24]. Many types of research also show the direct effect of walking on boosting creativity and mental well-being [25]. Walkability positively contributes to the environment. Walking to various destinations decreases the human environmental footprint from the use of fuel-based vehicles and, therefore, associated health and environment damaging air pollutions [7], [26], [27], [28], and [29]. Pedestrian-friendly urban development leads to a mass reduction in automobile dependency use and pollutions. Some scholars even argue for the role of walkable communities in counteracting the negative impacts of urban sprawl and natural environments damage in and near cities and metropolitan regions [30].

Furthermore, walkable environments can increase social interactions and economic opportunities [2]. For example, walkability plays an essential role in creating livable communities and public places that encourage social interactions. Livability also contributes to making places safer (including safety perception) and more enjoyable [7], and [31]. The walkability character also helps with reducing the crime rate in open spaces, making it a strategy in the design and development of some cities and communities [32].

Research also shows the effect of walkability on the economy. Some studies observed a high increase in shopping and trading in walking supportive commercial and mixed-use areas [33]. The city of Melbourne found a direct link between the city's economic growth and walkability characters [34]. Walkability also contributes to land value increase. A study on the value of over 4,200 the USA, office, retail, apartment, and industrial properties between 2001-2008 found a value increase by 6 to 54 percent in properties with a Walk Score of 80 compared to properties with a Walk Score of 20 [35]. The same study observed a consistent higher net operating income for the retail and office properties [35]. Similar findings were also observed in another comprehensive study on economic performance and walkability in Washington DC [36]. The walkable neighborhood is a core concept in contemporary urban theories like "Smart Growth" and "New Urbanism" [37].

\subsection{Walkability assessment}

Walkable environments and strategies cannot be designed and developed without assessing the existing ones. Walkability character in a built environment includes both quantitative objective characteristics (such as infrastructure and land use) and qualitative features (such as subjective aesthetic sensibility and sense of safety) [38]. A large number of walkability assessment papers reviewed for this and other studies categorize walkability's physical and non-physical characteristics within five major factors: functional, safety, aesthetic, destination, and comfort [7], [13], and [39]. Awon [40], [41], [42], and [43], walkability assessment studies focused on functional factors only, while the studies of [44], and [45], also include safety factor within their walkability assessment. The studies of [19] focus on aesthetic factors. [12]. [45], and [46] investigate and relate both aesthetics and comfort factors. The five factors and their subcategories are often ranked and/or weighted differently in different studies at the discretion 
of the researcher(s) [46]. The study of [47], and [48] considers functional factors as the most aspect of walkability, followed by destination, safety, comfort, and aesthetic factors respectively. The measurement of each factor is done through several sub-factors.

In his review of 25 pedestrian indices studies, [13] identifies intersection design, intersection distance, path design, path continuity, curb type, street width, traffic volume, traffic speed, and traffic sign as sub-factors of functionality. Some studies identify and variously measure some other functionality sub-factors such as gradient, path width, maintenance, corner, and type, sidewalk width, street design and type, traffic control devices, as well as parking [12] , [14], [49], [50], [51], and [52]. The path surface is an important subfactor for sidewalk functionality, discussed by some scholars [44], [47], and [53].

As an important walkability factor, safety is assessed through availability, distance, and quality of crossing, lighting, and anti-rigid and anti-slip floor [13], [15], [17], and [52]. Path high and surface are common safety features that also relate to functional and comfort factors [10], [52], and [53] . Lighting and Surveillance are too considered essential sub-factors for safety [54]. Safety also extends to cyclists and bike users. So, the availability of safe bike lane and parking facilities also contribute to safety factor [55], and [56].

The literature of walkability assessment identifies cleanliness, availability of gardens, open spaces, and trees, and lack of or limited car pollution as indicators and sub-factors for aesthetic [13], [19], and [26]. Destination, on the other hand, is represented through the availability of adequate access to public transportation, shops, and restaurants for pedestrians, as well as dedicated places for bicycles [10], [13]. Some scholars also consider on-street and off-street parking as destination sub factors [39], [57], [58], [59], [60], [61], and [62]. The availability of shadow (such as from tree canopies) for protection in inclement weather also contributes to destination factor [13].

The comfort factor refers to bringing pleasure to walking and avoiding boredom [13]. The subfactors of comfort often overlap with those in the other factors such as the existence of shops, restaurants, seats, and shadows for pedestrians and path and sidewalk type, height, and width, location of trees and lighting [13], [18]. Each of the factors and their sub-factors can be measured and assessed with one or more quantitative and/or qualitative methods (s) such as measurement, counting, observation, and pedestrian survey.

Assessing and calculating walkability can be done qualitatively and/or quantitatively. The Pedestrian Level Of Service (PLOS) is a walkability or pedestrian assessment method that has been used for quantified assessment [10]. Within this method, two main approaches (model) can be distinguished: capacity-based model and the second is a roadway characteristic-based model (see Figure 1). An extensive review by [10], for PLOS studies since the 1970s highlights the challenges in these studies and PLOS research. 


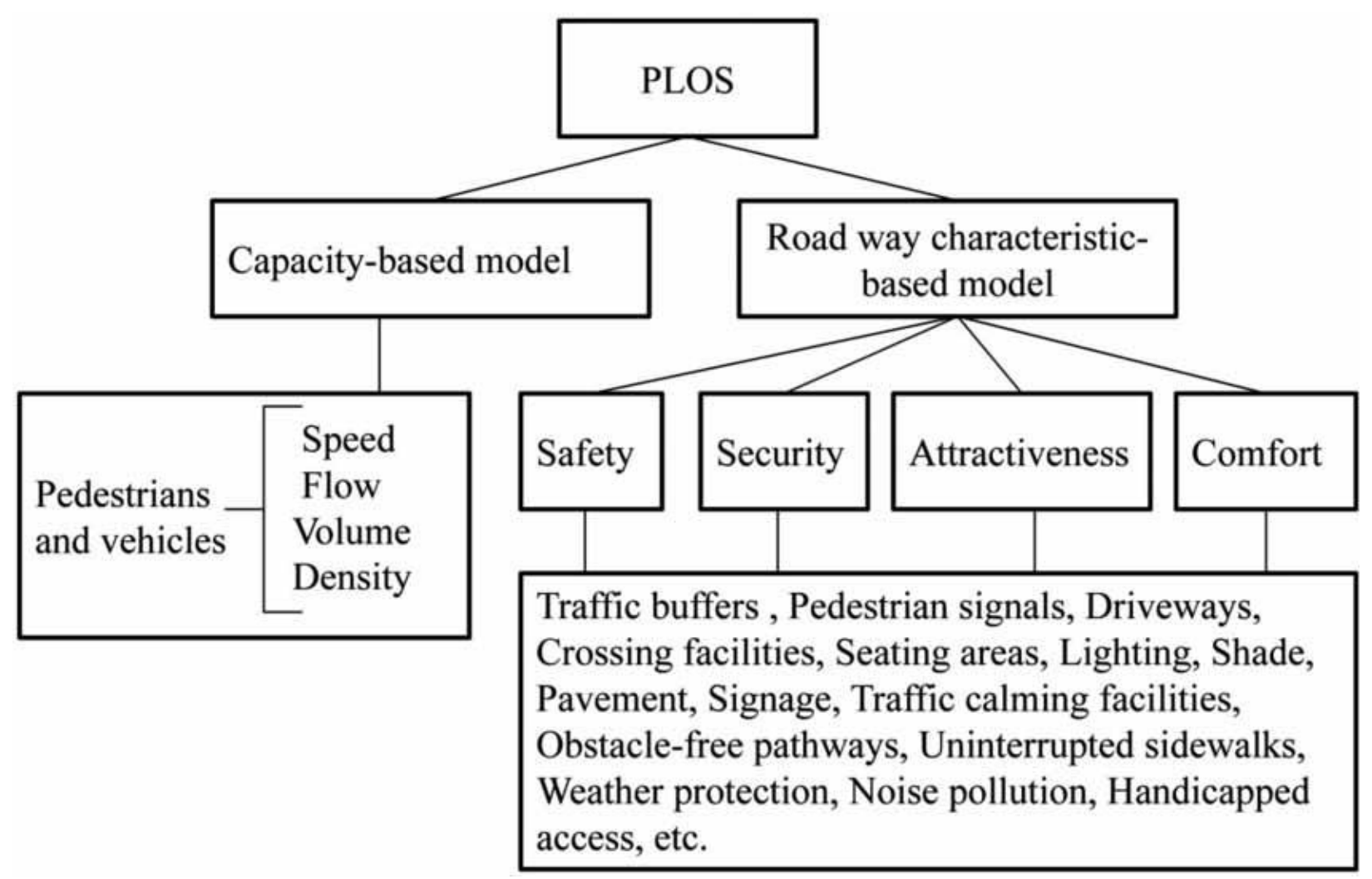

Figure 1. Two main approaches for evaluating PLOS [10].

\section{CASE STUDY}

The city of Sulaimani is the capital of Sulaimani Governorate in the Kurdistan Region of Iraq. Sulaimani is located north-east of Iraq and surrounded by a range of mountains. A 2018 census estimates the population of the city at 676,500 [63]. Although the area has a long history stretching from pre-history periods as evidenced by archaeological findings [64] the modern city of Sulaimani was founded in 1784 . The city has been officially recognized as "Capital of Culture" of the Kurdistan Region of Iraq and (most recently) a UNESCO Creative City in literature. Social and cultural vibrancy in the city's public places has been part of the city's development and growth over the last few centuries.

In addition to working as a hub for connecting most of the city's commercial, social, and cultural activities, the historic city center Sulaimani has been playing a vital and symbolic role in the city's history. Many Kurdish history-changing events took place in the Bardarki Sarai square at the heart of the city center [65]. A pedestrian survey by [65], [66] found that senior male residents of the city visit Bardarki Sarai and its surrounding coffee shops on daily basis because of their strong emotional connections and memories with the place. The same survey found that the younger population visit the historic center for shopping and gathering [66]. Over centuries, the main city center square became a symbol of resistance, pride, and national identity. The strong symbolism and historic vibrant social and cultural aspects of Sulaimani's city center made it an attractive destination for the city visitors and tourists. The center also includes some significant historical buildings and landmarks such as the Sarai building and the Great Mosque. 
Bardarki Sarai square connects six mixed-use one way streets Mawlawy, Goran, Sabunkaran, Bekas, Kawa, and Peramerd, four of them named after famous poets from history (Figure 2).

The streets vary in their length and width. With a length of $730 \mathrm{~m}$, Sabunkaran is the longest among the six streets, followed by Mawlawy (645 m), Kawa (537 m), Peramerd (530 m), Goran $(460 \mathrm{~m})$, and Bekas $(155 \mathrm{~m})$, respectively. With $25 \mathrm{~m}$ width, Goran street is the widest among them, followed by Peramerd and Bekas at a width of $20 \mathrm{~m}$. The width of the remaining three streets is $15 \mathrm{~m}$.

Bardarki Sarai and the connected street areas have the highest pedestrian volume and visitors from different places in the city. It includes commercial buildings, shopping, and restaurants in or around historical buildings and the oldest residential areas in the city. In addition to attracting people, these changes are also bringing a massive volume of automobiles. These changes are transforming the historic city center and its adjacent vibrant streets into streets with high congestion, threatening their social and cultural characters in the long-term.

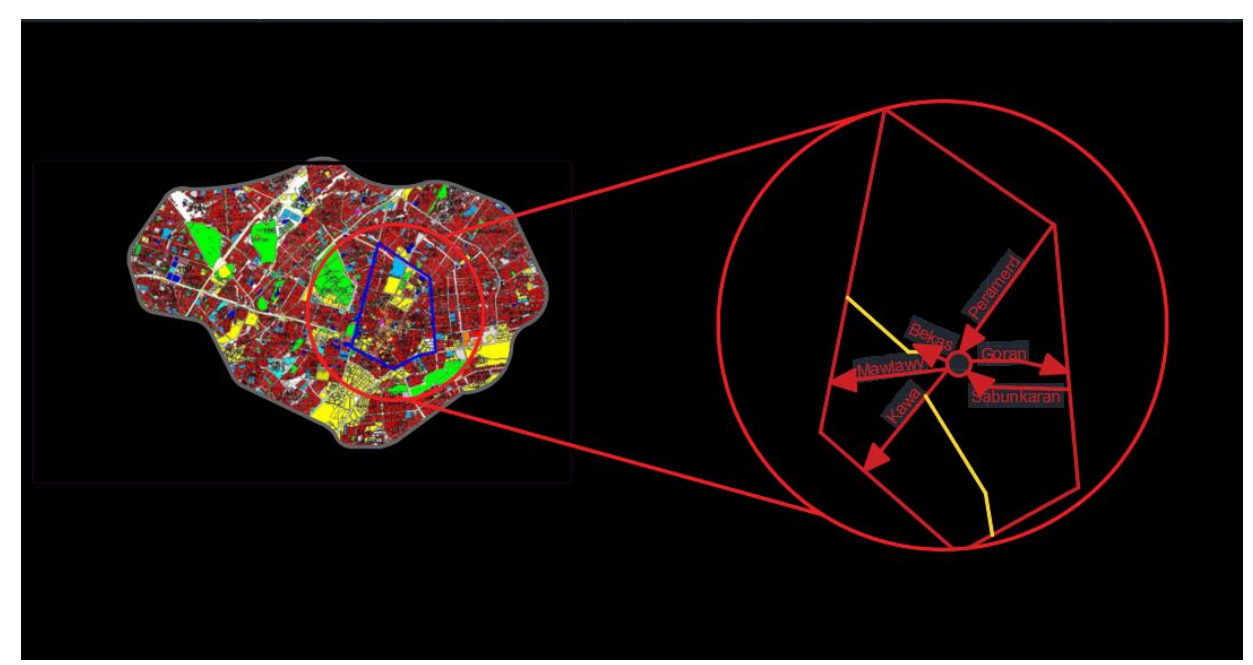

Figure 2: The six connecting streets at Bardarki Sarai square in Sulaimani city center (source: author).

Similar to the streets of other Iraqi cities, lack of regular maintenance, walkway deterioration from the end of design life, adjacent shops' illegal exploitation of sidewalk right of way with no or limited actions against these violations, are affecting the state of walkability in these streets [66]. Pedestrian and automobile movements in these streets are increasingly mixing from lack or poor road markings, signage, and traffic violation enforcement, further deteriorating the state of walkability and degrading the environment. With officially joining the EU Covenant of Mayors, the Sulaimani Governorate, more than before, needs to control the high traffic congestion across the city (including in the city center) and adopt sustainable (re)development principles and measures (including walkability) [67]. Without such measures and systematic assessments, it will be difficult for the city of Sulaimani to contribute to its Governorate's commitment to the ambitious EU 40\% greenhouse gas reduction target by 2030, as outlined in the Sustainable Energy Action Plan (SEAP) [67].

This study systematically measures, quantifies, and asses walkability in the six commercial streets in the city center of Sulaimani. The study aims at establishing the first baseline research for the state of walkability in the city center of Sulaimani as a case study for other cities in Iraq and a similar context. Additionally, the findings from the study information and guides urban planners, designers, and policymakers in making informed sustainable decisions and planning and contributing to Governorate's SEAP objectives. 


\section{METHODS AND MATRIAL}

As discussed in the literature review, assessing the state of the walkability of any environment can be undertaken through several quantitative and qualitative methods. The study acknowledges that a comprehensive walkability assessment requires combining data collection and analysis of objective and subjective features. However, with the scope and focus of the current study, the number of streets, and page limitations, for this paper we only collect and analyze quantitative and qualitative data related to the functional, safety, destination, aesthetic, and comfort of the physical environment of the streets. These data are collected through extensive physical feature measurements during field survey and observation and photo analysis in 4 months from March to June 2019. The data from each factor and sub-factors are then analyzed and compared to corresponding standards from the literature discussed in the previous section or cited in the tables.

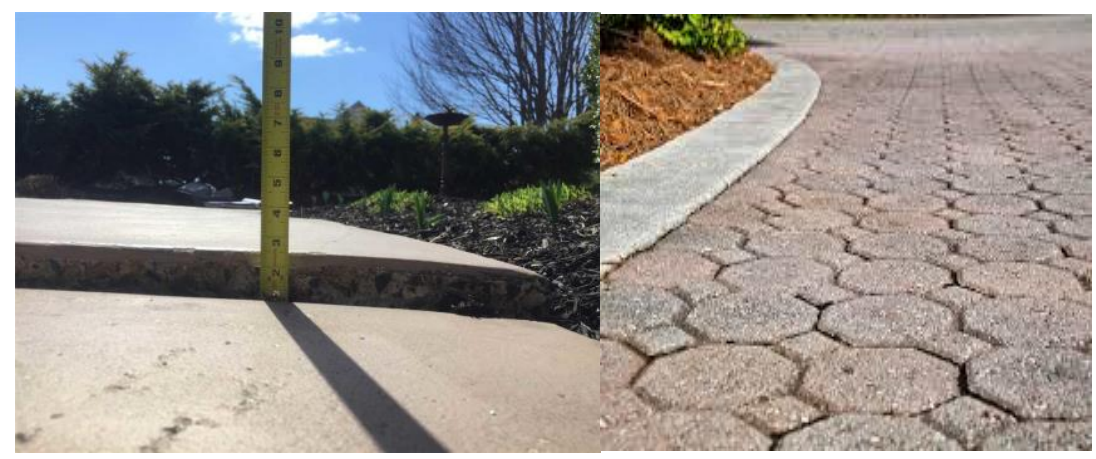

Figure 3. Data collection methods for the study (source: [19])

\section{DATA COLLECTION}

\subsection{Measurement of physical features}

To accurately assess the physical performance of each street, we carried out an extensive counting for the number and type of all the walkability related physical features within the streets, such as street furniture (power pole, trees, trash bin, bench) and their location as well as the detailed measurement of the elements such as sidewalk length, width, high, slope, and gradient (Figure 4).

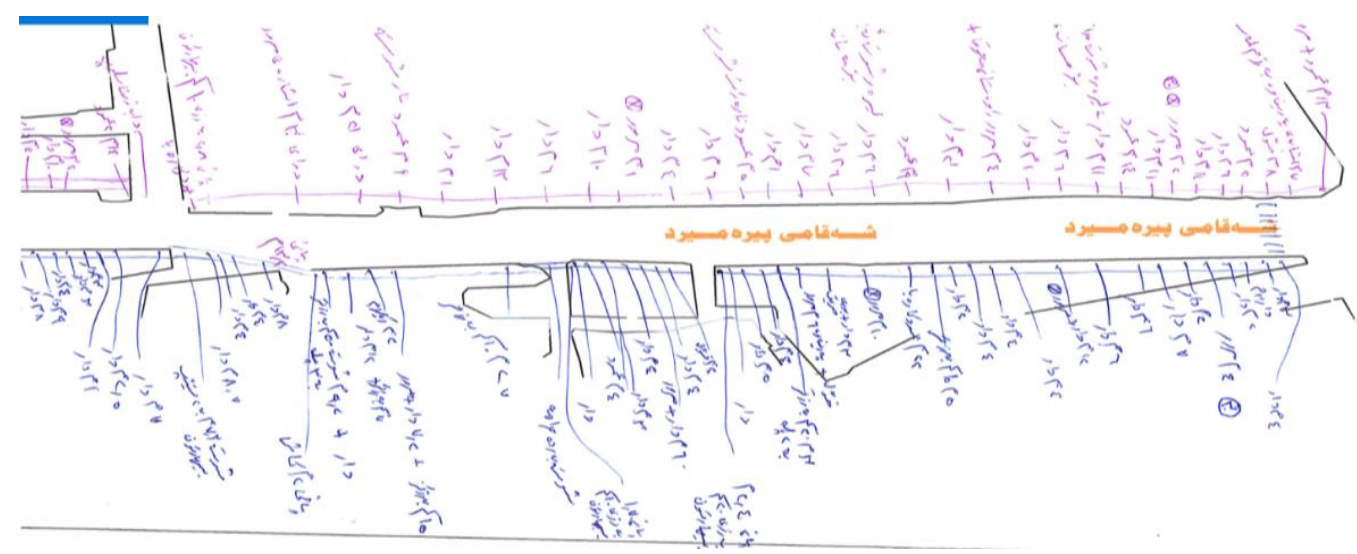

Figure 4: Example of field notes from a detailed measurement of the part of Peramerd street (source:

author). 


\subsection{Observation and photo analysis}

For the data that cannot be collected through counting or measurement such as surface material types, condition, and quality, we used informed qualitative observation from the literature [68]. In addition to on-site direct observation and note-taking, we also took and analyzed photos from various parts of the streets for increasing the accuracy of the observation.

\section{RESULTS AND DISCUSSION}

The quantitative and qualitative measurements and observations of the six streets revealed a large discrepancy and variation among and within the streets of Sulaimani city center in many aspects and factors, indicating lack of or limitations in urban planning and design guidelines and enforcement measures. Field observation of pedestrians' behavior revealed that the large variation and inconsistency in the sidewalks' width, height, and surface materials (see Table 1) are negatively affecting the quality (ergonomic and safety) of walking in those streets. The mix of pedestrian and cars in the streets are mainly caused by the poor quality and conditions of the sidewalks that potentially increases pedestrian-car collisions.

Table 1: Measurements from the six streets (source: author).

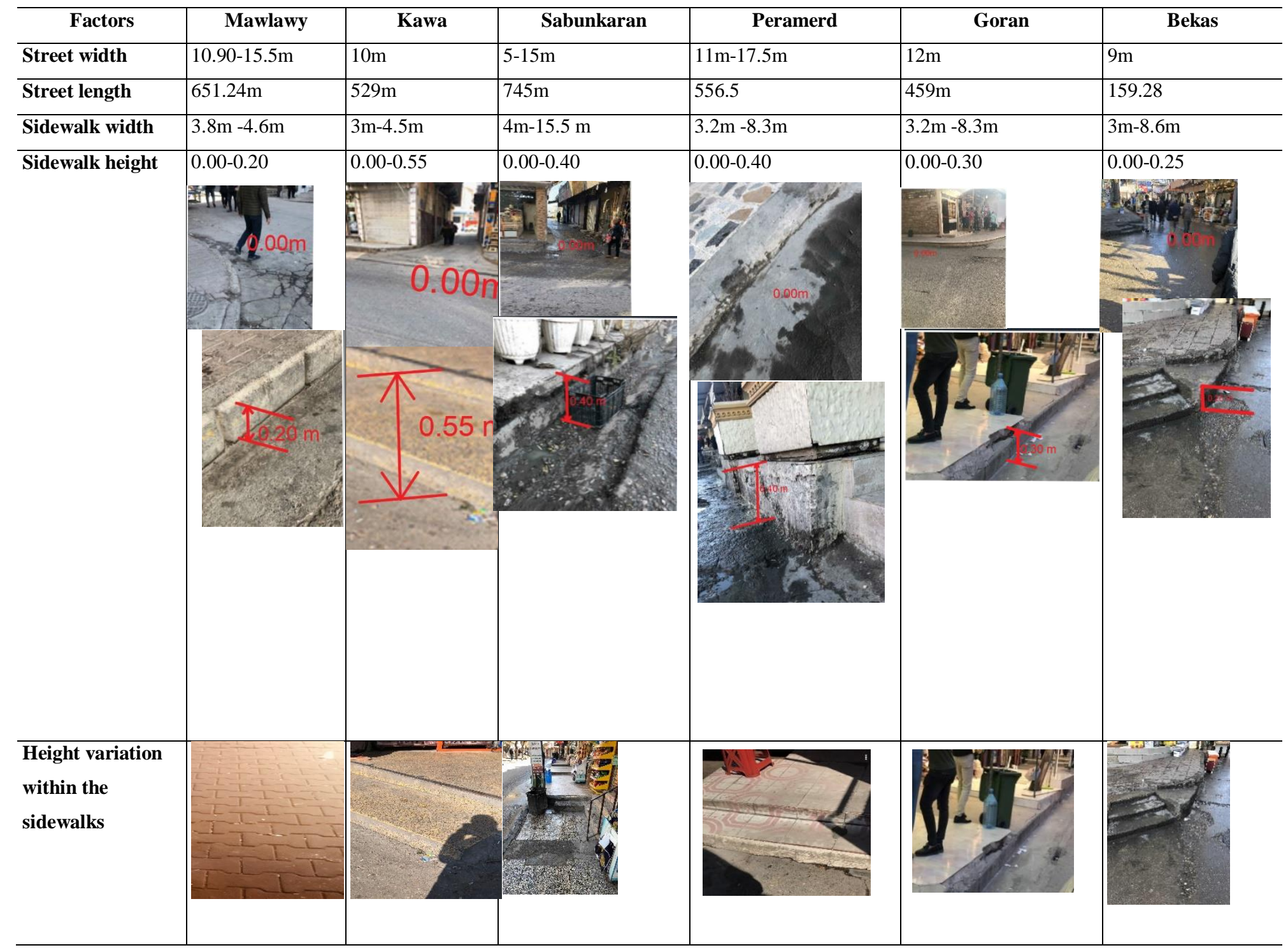




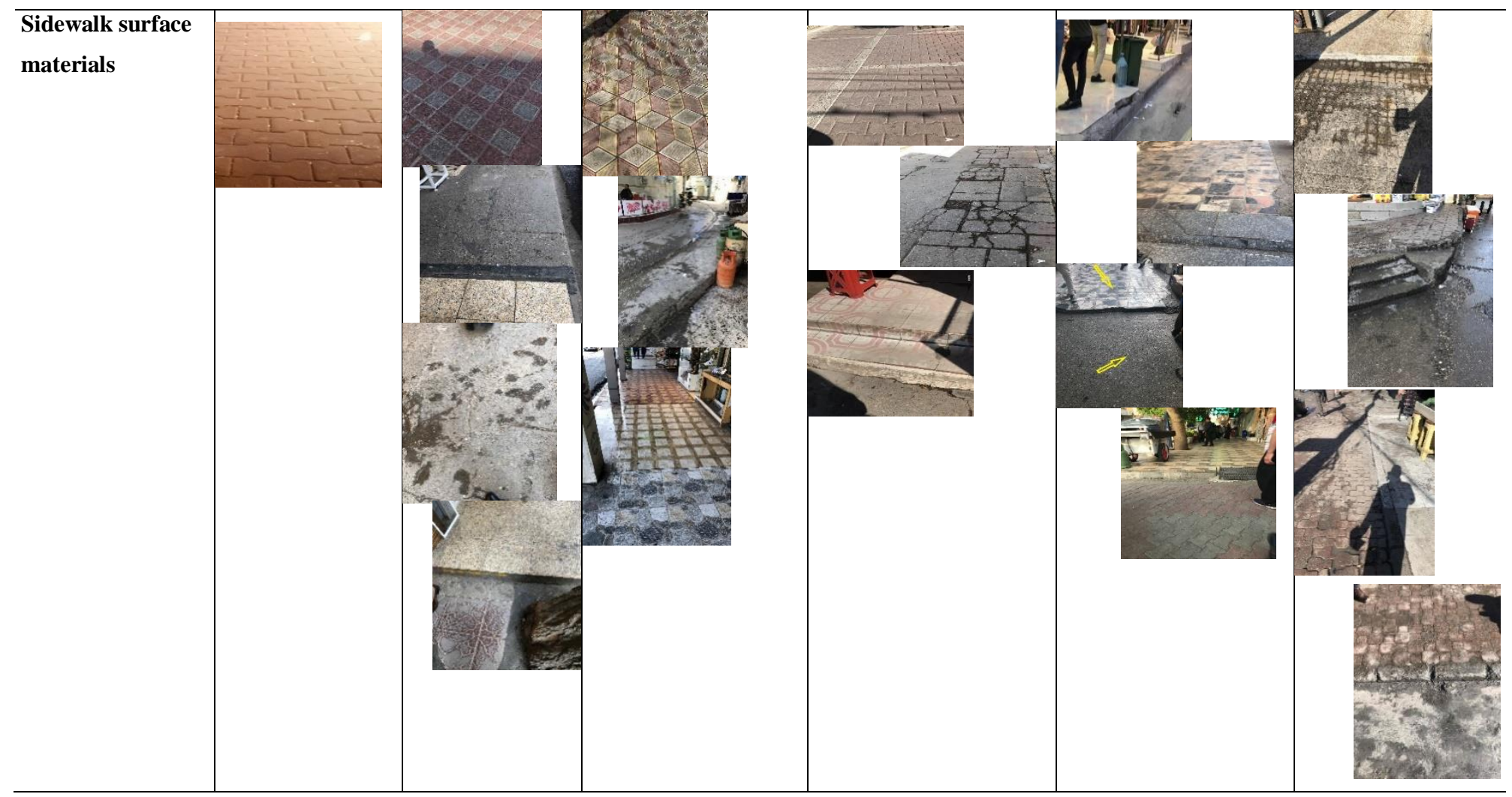

Only 1 (Mawlawy) out of 6 streets has garbage bins on its sidewalks and even those randomly distributed decreasing the cleanliness of the sidewalks and streets and increasing time and efforts of cleaning by municipality cleaners in evening hours. All the streets include crossing, parking, and no-stopping (clearway) signs for regulating pedestrians and car movements. Yet, Mawlawy is the only street that has a pedestrian crossing line marked on the street. Only two streets (Sabunkaran and Peramerd) include signs for the wheelchair. While one or more hotel exists in all the streets, two of the streets (Mawlawy and Goran) do not have a sign to inform about that. Trees (at various types, height, and number) are available in all the streets. However, for most, their distribution is irregular. The power pole number and distribution are of low quality in the vast majority of the streets. Half of the streets do not have any speed control signs that can regulate the speed limit within these heavy pedestrian streets (see Table 2).

Table 2: Sidewalk furniture in the six streets (source: author).

\begin{tabular}{l|l|l|l|l|l|l}
\hline Factors & Mawlawy & Kawa & Sabunkaran & Peramerd & Goran \\
\hline $\begin{array}{l}\text { Existence of } \\
\text { garbage bin for } \\
\text { pedestrians }\end{array}$ & & &
\end{tabular}




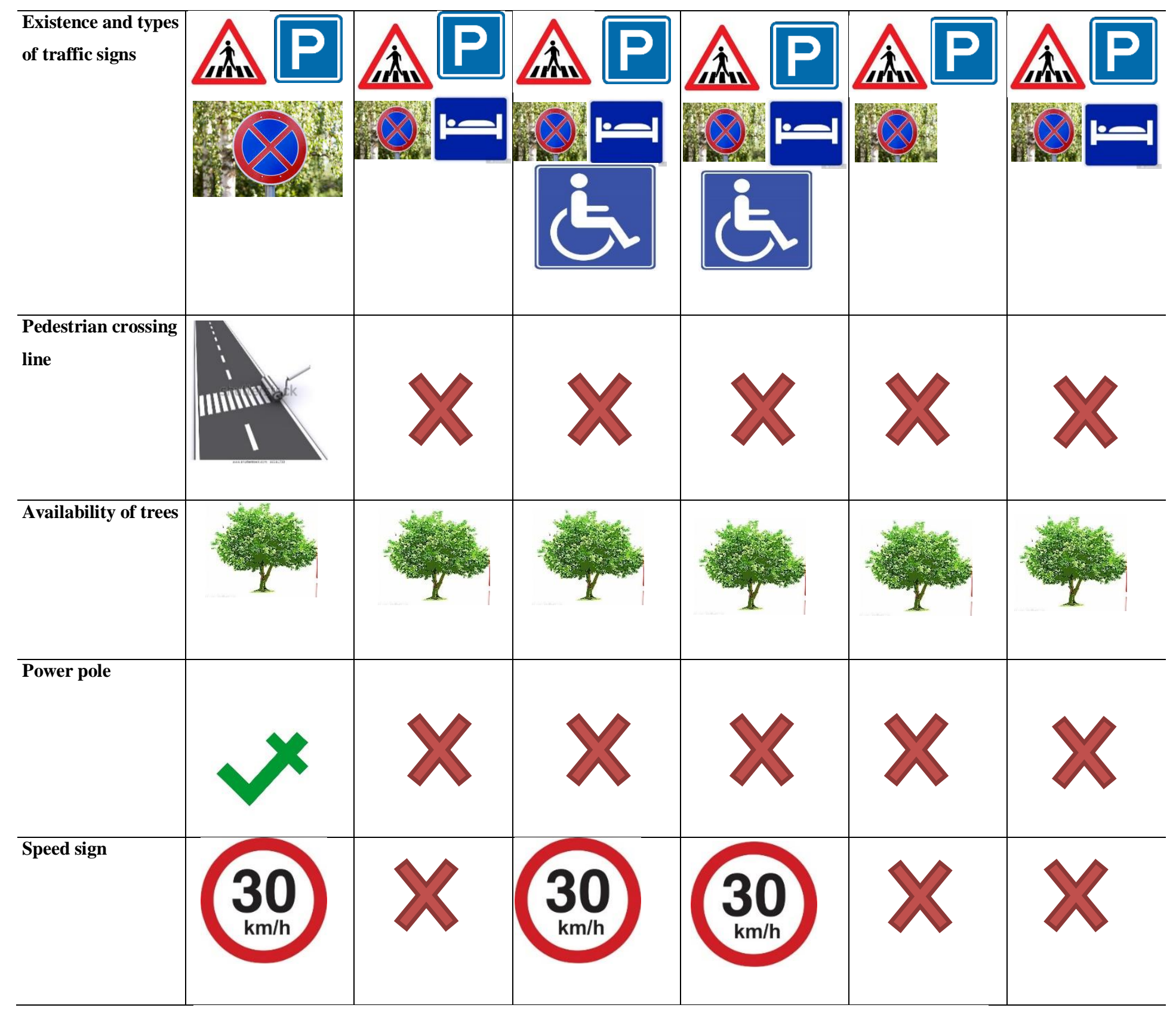


Table 3: Lane direction and intersections in the six streets (source: author).

\begin{tabular}{|c|c|c|c|c|c|c|}
\hline Factors & Mawlawy & Kawa & Sabunkaran & Peramerd & Goran & Bekas \\
\hline Line lane & & & & & & \\
\hline Intersection & $\begin{array}{l}\text { There are two types } \\
\text { of intersection in } \\
\text { this street first } \\
\text { picture is the type } \\
\text { which cut the } \\
\text { continuity of the } \\
\text { sidewalk and the } \\
\text { other one does not } \\
\text { cut the continuity of } \\
\text { the sidewalk }\end{array}$ & $\begin{array}{l}\text { All intersections are } \\
\text { cutting the continuity } \\
\text { of the sidewalks }\end{array}$ & $\begin{array}{l}\text { All intersections are } \\
\text { cutting the } \\
\text { continuity of the } \\
\text { sidewalks }\end{array}$ & $\begin{array}{l}\text { All intersections } \\
\text { are cutting the } \\
\text { continuity of the } \\
\text { sidewalks }\end{array}$ & $\begin{array}{l}\text { Pond } \\
\text { All intersections are cutting } \\
\text { the continuity of the } \\
\text { sidewalks }\end{array}$ & $\begin{array}{l}\text { All intersections } \\
\text { are cutting the } \\
\text { continuity of the } \\
\text { sidewalks }\end{array}$ \\
\hline
\end{tabular}

The above and additional sub factors measurements and observations for the five factors in the six streets are compared to some standards adapted from the research of [68]. For comparison to the standards, some of the sub-factors required calculation, and their values are represented as PI (Pedestrian Indicator). The assessment of the remaining sub-factors, which did not require or could not be calculated, was done through observation. The total performance score for each factor in a street represents the number of sub-factors that comply with the related standard or requirement in the street divided by the total number of sub-factors in a factor. Due to the scope of the research and resources, data about the land use and urban design quality factors were not collected. Instead, an extensive pedestrian survey was carried out for comparison with the physical feature assessment of the streets. Due to paper length limitation and the amount of collected data, this paper reports results from the physical features measurements and observations.

\subsection{Functional factor:}

As it appears in Table 4 and Figure 6, except for Mawlawy Street, the measurements and observations from the majority of Sulaimani city center's main streets fall far short in functional factor (a performance score of under 25\%). Many sub-factors are either missing or non-standard 
in five out of the six streets. With a functional performance score of $13 \%$, Bekas street's functional factor scores the lowest among the six streets. Mawlawy has the highest performance in functional factors $(60 \%)$.

Table 4: Functional sub-factors calculation and comparison to standards (source: author).

\begin{tabular}{|c|c|c|c|c|c|c|}
\hline Sub factors & Mawlawy & Kawa & Sabunkaran & Peramerd & Goran & Bekas \\
\hline \multicolumn{7}{|c|}{ Sidewalk Gradient } \\
\hline Maximum height $=\mathbf{0 . 9 1 m ~ [ 2 9 ] ~}$ & $\mathrm{X}$ & $\mathrm{X}$ & $\mathrm{X}$ & $\mathrm{X}$ & $\mathrm{X}$ & $\mathrm{X}$ \\
\hline Provided every 400m [29] & $\sqrt{ }$ & $\mathrm{X}$ & $\mathrm{X}$ & $\mathrm{X}$ & $\mathrm{X}$ & $\mathrm{X}$ \\
\hline $\begin{array}{l}\text { PI=C/N } \\
\text { C= Length of the street with } \\
\text { standard accessibility for a } \\
\text { wheelchair, fountain for drinking } \\
\text { + their support length (m) } \\
\text { N= length of the street (m) }\end{array}$ & $\begin{array}{c}\mathrm{PI}=0.10 \mathrm{~m} \leq 5 \\
\sqrt{ }\end{array}$ & $\begin{aligned} & \mathrm{PI}=0 \\
& \mathrm{X}\end{aligned}$ & $\mathrm{PI}=0$ & $\mathrm{PI}=0$ & $\mathrm{PI}=0$ & $\mathrm{PI}=0$ \\
\hline \multicolumn{7}{|l|}{ Sidewalk grade should be $\leq \mathbf{5}$ [29] } \\
\hline \multicolumn{7}{|c|}{ Curb type } \\
\hline slope is \% 2 [69] & $\sqrt{ }$ & $\mathrm{X}$ & $\mathrm{X}$ & $\mathrm{X}$ & $\mathrm{X}$ & $\mathrm{X}$ \\
\hline $\begin{array}{l}\mathrm{PI}=\mathrm{C} / \mathrm{N} \\
\mathrm{C}=\mathrm{No} \text {. of standard curb ramps } \\
\mathrm{N}=\text { No. Of needed curb ramps in } \\
\text { the street } \\
\mathrm{PI}=1 \text { if } \mathrm{P}>=1 \\
\mathrm{PI}=\mathrm{P} \text { if } \mathrm{p}<1 \\
\mathrm{PI}=0 \text { there is no ramp or that the } \\
\text { street does not require one }[69]\end{array}$ & $\begin{array}{l}\mathrm{PI}=\mathrm{P} \\
0.5\end{array}$ & $\mathrm{PI}=0$ & $\mathrm{PI}=0$ & $\mathrm{PI}=0$ & $\mathrm{PI}=0$ & $\mathrm{PI}=0$ \\
\hline
\end{tabular}

$\mathrm{PI}=\sum_{i=1}^{K} \mathrm{DICi} x \mathrm{Li} /($ street length

$\mathrm{PI}=1.12 \quad \mathrm{PI}=0.87 \quad \mathrm{PI}=33.66$

(both sides)- Intersections length)

$\mathrm{i}=1,2,3, \ldots . ., \mathrm{k}$ (Variation in

footpath width across various

parts of the street)

$\mathbf{P C}_{\mathrm{i}}=\mathbf{C}_{\mathrm{I}} / \mathbf{N}_{\mathrm{i}}$

$\mathrm{C}_{\mathrm{i}}=$ the sidewalk area with the

standard slope in section $\mathrm{i}\left(\mathrm{m}^{2}\right)$

$\mathrm{N}_{\mathrm{i}}=$ Street length (in section $\left.\mathrm{i}\right) * \mathrm{~W}$

If $W>=1.5 \mathrm{~m}$

$\mathbf{L}_{\mathrm{i}}=$ Street length (in section $\left.\mathrm{i}\right) * \mathbf{W}$

If $\mathrm{W}>=\mathbf{1 . 5 \mathrm { m }}$

$\mathbf{L}_{\mathrm{i}}=$ Street length (in section $\left.\mathrm{i}\right)(\mathrm{m})$

Between 0.6-1.25 [41]

\begin{tabular}{|c|c|c|c|c|c|c|}
\hline $\begin{array}{l}\mathrm{PI}=\sum_{i=1}^{K} \text { DICixLi /(street length } \\
\text { (both sides)- Intersections length) } \\
\mathrm{i}=1,2,3, \ldots ., \mathrm{k} \text { (Variations in } \\
\text { footpath across various parts of } \\
\text { the street) } \\
\text { DIC }_{\mathrm{i}}=\mathrm{C}_{\mathrm{I}} / \mathrm{N}_{\mathrm{i}} \\
\mathrm{C}_{\mathrm{i}}=\text { the sidewalk area with the } \\
\text { standard slope in section } \mathrm{i}\left(\mathrm{m}^{2}\right) \\
\left.\mathrm{N}_{\mathrm{i}}=\text { street length (in section } \mathrm{i}\right) * 1.5\end{array}$ & $\begin{array}{c}\mathrm{PI}=0.98 \leq \% 2 \\
\sqrt{ }\end{array}$ & $\begin{array}{c}\mathrm{PI}=1.44 \leq \% 2 \\
\sqrt{ }\end{array}$ & $\begin{array}{c}\mathrm{PI}=0.95 \leq \% 2 \\
\sqrt{ }\end{array}$ & $\begin{array}{c}\mathrm{PI}=1.12 \leq \% 2 \\
\sqrt{ }\end{array}$ & $\begin{array}{c}\mathrm{PI}=0.87 \leq \% 2 \\
\sqrt{ }\end{array}$ & $\begin{array}{c}\mathrm{PI}=33.66 \neq 02 \\
\mathrm{X}\end{array}$ \\
\hline
\end{tabular}


If $\mathrm{W}<\mathbf{1 . 5 m}$

$\mathrm{N}_{\mathrm{i}}=$ street length (in section $\left.\mathrm{i}\right) * \mathrm{~W}$

If $\mathbf{W}>=\mathbf{1 . 5 m}$ [29], [69]

$\mathbf{L}_{\mathrm{i}}=$ street length (in section i) (m)

Sidewalk slope $\leq \% 2$ [69]

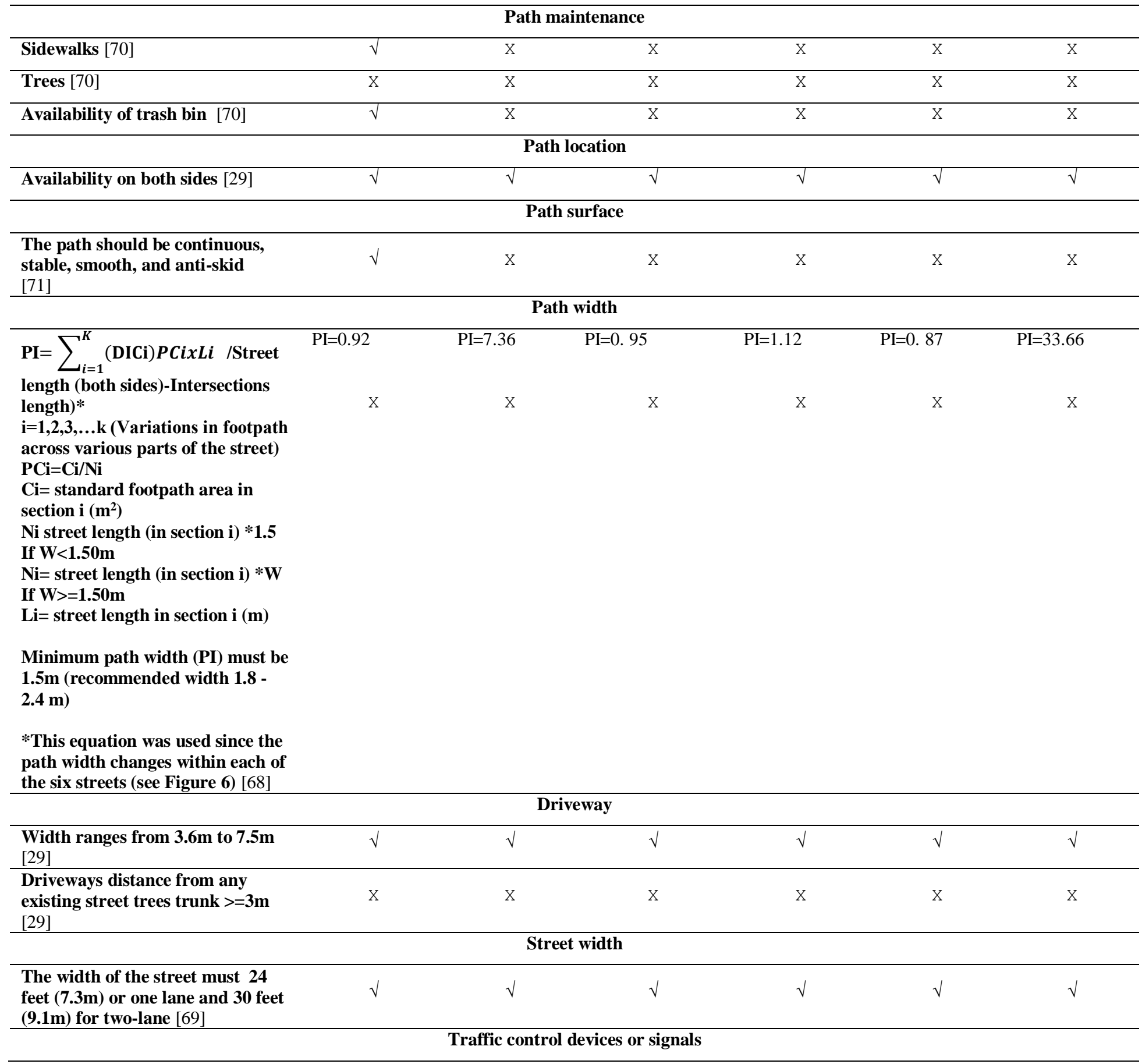




\begin{tabular}{|c|c|c|c|c|c|c|}
\hline $\begin{array}{l}\text { The pedestrian crossing signals } \\
\text { must be located at least } \mathbf{3 m} \text { from } \\
\text { the crossing [29], [69] }\end{array}$ & $\sqrt{ }$ & $\mathrm{X}$ & $\mathrm{X}$ & $\mathrm{X}$ & $\mathrm{x}$ & $\mathrm{x}$ \\
\hline $\begin{array}{l}\text { A distance of 1.5m between traffic } \\
\text { signals [29], [69] }\end{array}$ & $\sqrt{ }$ & $x$ & $x$ & $x$ & $x$ & $\mathrm{X}$ \\
\hline $\begin{array}{l}\text { Availability of adequate } \\
\text { countdown timer [29], [69] }\end{array}$ & $x$ & $x$ & $\mathrm{X}$ & $\mathrm{X}$ & $\mathrm{X}$ & $\mathrm{X}$ \\
\hline $\begin{array}{l}\text { The button should be reachable } \\
\text { by wheelchair users [29], [69] }\end{array}$ & $x$ & $x$ & $\mathrm{X}$ & $X$ & $x$ & $\mathrm{X}$ \\
\hline $\begin{array}{l}\text { Availability of audible signal [29], } \\
\text { [69] }\end{array}$ & $x$ & $X$ & $\mathrm{X}$ & $X$ & $x$ & $\mathrm{X}$ \\
\hline \multicolumn{7}{|c|}{ Tactile pavement } \\
\hline $\begin{array}{l}\text { Availability of tactile pavement } \\
{[29]}\end{array}$ & $\mathrm{X}$ & $x$ & $X$ & $X$ & $X$ & $\mathrm{X}$ \\
\hline \multicolumn{7}{|c|}{ On-street parking } \\
\hline $\begin{array}{l}\text { Availability of on-street vehicle } \\
\text { parking [29] }\end{array}$ & $\mathrm{x}$ & $x$ & $\mathrm{x}$ & $\mathrm{X}$ & $\mathrm{x}$ & $\mathrm{x}$ \\
\hline Total & $\% 60$ & $\% 17$ & $\% 21$ & $\% 21$ & $\% 21$ & $\% 13$ \\
\hline
\end{tabular}

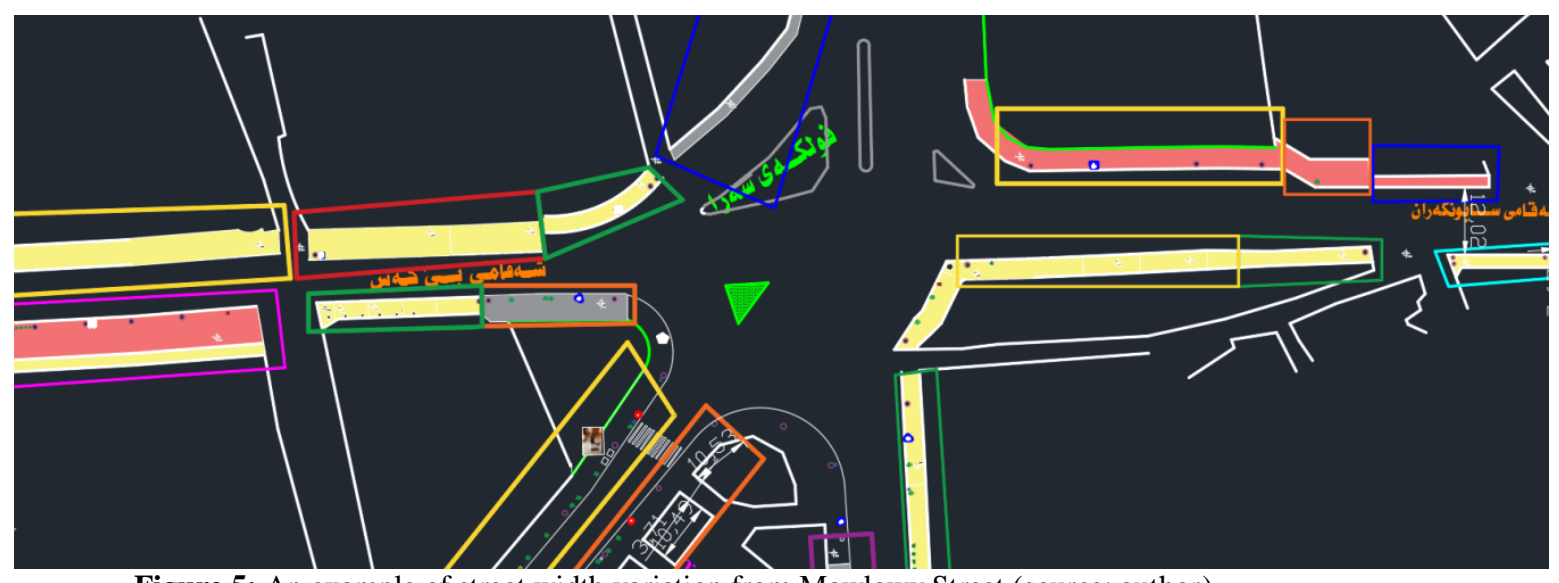

Figure 5: An example of street width variation from Mawlawy Street (source: author).

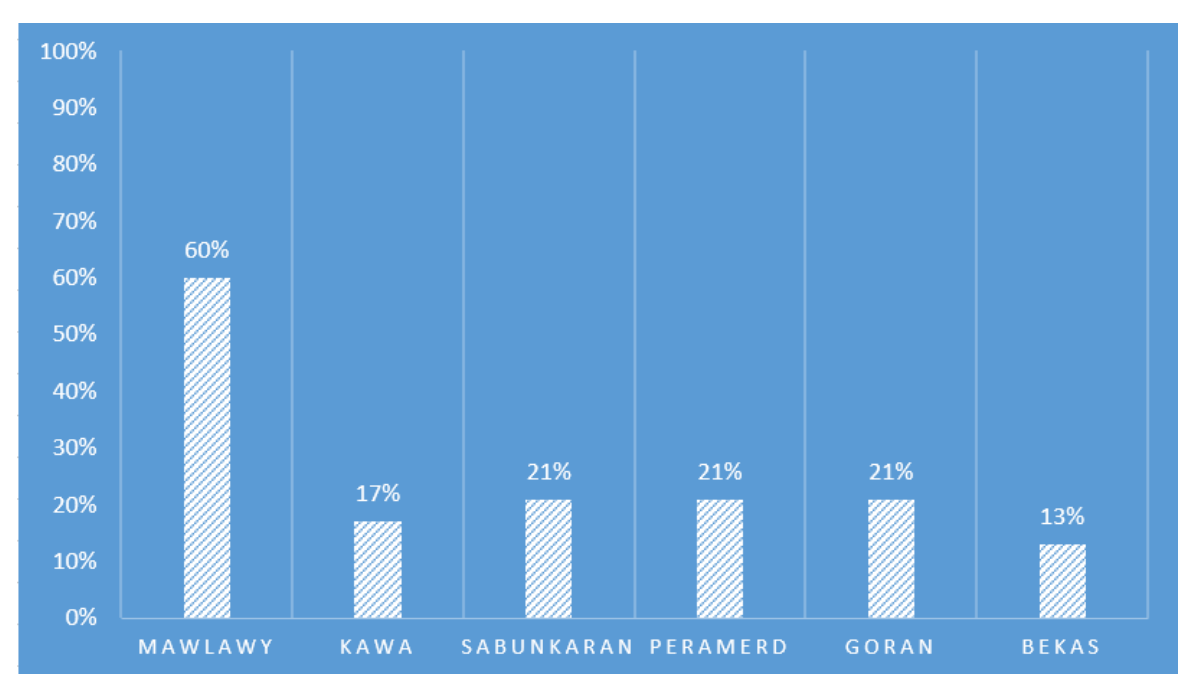

Figure 6: Functional factor average performance comparison among the six streets (source: author). 


\subsection{Safety factor}

Table 5 summarizes safety sub-factors (crossing aids, midblock crossing, and lighting) measurement and observation and calculate each street's total safety performance. As it appears, five out of the six streets score zero in all those sub-factors. At a 57\% performance, Mawlawy street is the only city center street that has some of those safety sub factors available or meeting the standards (Figure 7). It should be noted that in checking lighting availability and functioning sub-factors for Mawlawy street, the overall state was considered and that lighting in some poles is not maintained and some of the poles are not originally placed for lighting.

Table 5: Safety sub factors calculation and comparison to standards (source: author).

\begin{tabular}{|c|c|c|c|c|c|c|}
\hline Sub factors & Mawlawy & Kawa & Sabunkaran & Peramerd & Goran & Bekas \\
\hline \multicolumn{7}{|c|}{ Crossing aids (continental pattern) } \\
\hline $\begin{array}{l}\mathrm{PI}=\mathrm{C} / \mathrm{N} \\
\mathrm{C}=\mathrm{No} \text { of standard crosswalk } \\
\text { markings } \\
\mathrm{N}=\text { No. of needed crosswalks in the } \\
\text { street (Intersections crosswalk and } \\
\text { mid-block) } \\
\mathrm{PI}=1 \quad \text { If } \mathbf{p}>=\mathbf{1} \\
\mathrm{PI}=\mathrm{P} \quad \text { if } \mathrm{P}<\mathbf{1}[68]\end{array}$ & $\begin{array}{c}\mathrm{PI}=0 \\
\mathrm{X}\end{array}$ & $\begin{array}{c}\mathrm{PI}=0 \\
\mathrm{X}\end{array}$ & $\begin{array}{c}\mathrm{PI}=0 \\
\mathrm{X}\end{array}$ & $\begin{array}{c}\mathrm{PI}=0 \\
\mathrm{X}\end{array}$ & $\begin{array}{c}\mathrm{PI}=0 \\
\mathrm{X}\end{array}$ & $\begin{array}{c}\mathrm{PI}=0 \\
\mathrm{X}\end{array}$ \\
\hline $\begin{array}{l}\text { Strip width ranges between } 0.3 \text { - } \\
0.6 m[29]\end{array}$ & $\sqrt{ }$ & $\mathrm{x}$ & $\mathrm{x}$ & $\mathrm{x}$ & $\mathrm{x}$ & $\mathrm{x}$ \\
\hline
\end{tabular}

\section{Midblock crossing}

\section{Crosswalk frequency}

$\mathbf{P I}=$

$\sum \frac{\mathrm{pi}}{\text { total }}$ number of sections that

PI=0 If total length of street $<120 \mathrm{~m}$ and $\mathrm{ci}=\mathbf{0}$

Pci=ci/ni

$\mathrm{PI}=1 \quad \mathrm{PI}=0$

$\sqrt{ }$

$\mathrm{X}$
$\mathrm{PI}=0$

$\mathrm{X}$
$\mathrm{PI}=0$

$\mathrm{X}$
$\mathrm{PI}=0$

$\mathrm{X}$

$I=1,2,3, \ldots . . . k$ (different parts of street

between intersections $>120 \mathrm{~m}$ )

$c i=$ No. of standard mid-block

crossing in section $i$

ni= length of street in section $\mathrm{i} / \mathbf{1 2 0}$

[69]

\begin{tabular}{|c|c|c|c|c|c|c|}
\hline \multicolumn{7}{|c|}{ Lighting } \\
\hline $\begin{array}{l}\text { Lighting poles "should be centered a } \\
\text { min of } 0.9 \mathrm{~m} \text { off the face of curb and } \\
\text { from any accessible structure such } \\
\text { as shelter" [74] }\end{array}$ & $\sqrt{ }$ & $x$ & $x$ & $\mathrm{X}$ & $x$ & $x$ \\
\hline $\begin{array}{l}\text { It should be full cut off fixtures and } \\
\text { downwards lighting [74] }\end{array}$ & $\sqrt{ }$ & $\mathrm{X}$ & $X$ & $X$ & $X$ & $X$ \\
\hline
\end{tabular}




\begin{tabular}{|c|c|c|c|c|c|c|}
\hline $\begin{array}{l}\text { The lighting poles should be 9m } \\
\text { (max.) apart [74] }\end{array}$ & $\mathrm{x}$ & $\mathrm{x}$ & $\mathrm{X}$ & $\mathrm{x}$ & $\mathrm{X}$ & $\mathrm{x}$ \\
\hline Availability of tactile pavement [74] & $\mathrm{x}$ & $\mathrm{x}$ & $\mathrm{x}$ & $\mathrm{x}$ & $\mathrm{X}$ & $\mathrm{x}$ \\
\hline Total & $\% 57$ & $\% 00$ & $\% 00$ & $\% 00$ & $\% 00$ & $\% 00$ \\
\hline
\end{tabular}

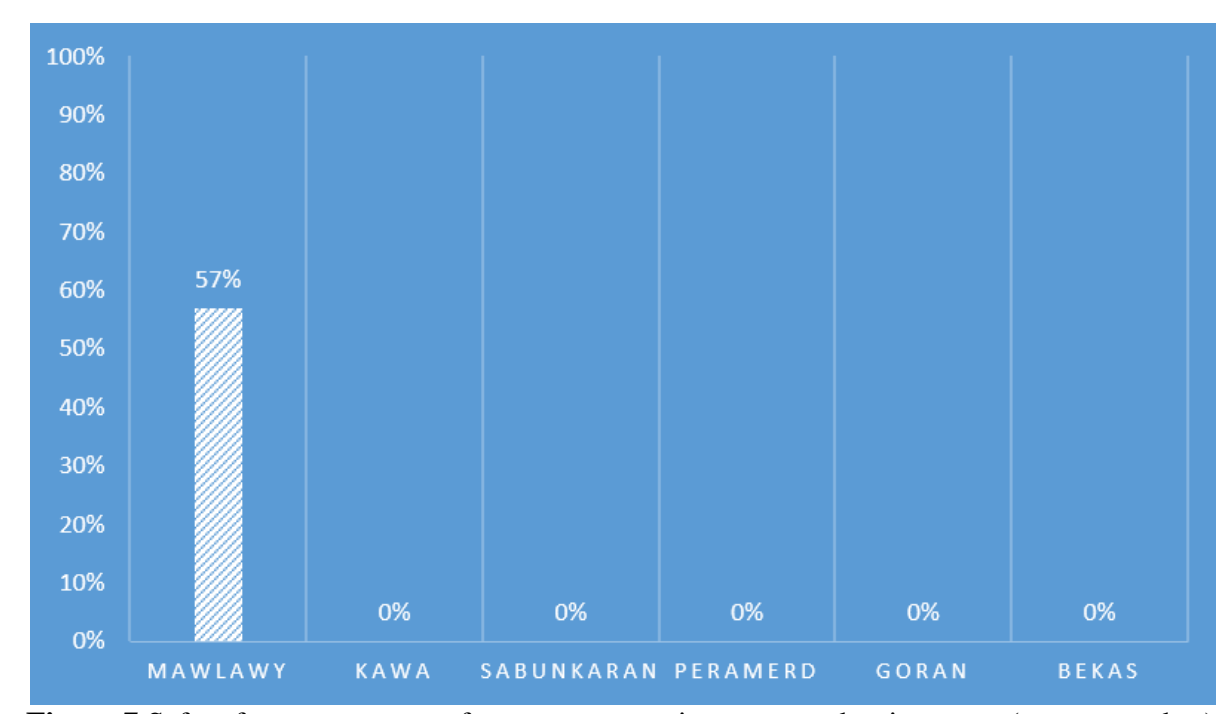

Figure 7 Safety factor average performance comparison among the six streets (source: author).

\subsection{Aesthetic factor}

Among the calculated and observed aesthetic sub factors presented in Table 6, the high majority of the streets perform low (Figure 8). The only aesthetic related sub-factor checked in all the streets is the availability of trees on both sides of the streets. While this is true in all the six city center streets, the vast variation in the trees canopy, height, and types suggest a lack of planning and guidelines in planting and maintaining those trees. In addition to the availability of tress on both sides of the street, Mawlawy street observation revealed better Pothole maintenance and curb repairs. This has increased the street's performance to $23 \%$.

Table 6: Aesthetic sub-factors calculation and comparison to standards (source: author).

\begin{tabular}{|c|c|c|c|c|c|c|}
\hline Sub factors & Mawlawy & Kawa & Sabunkaran & Peramerd & Goran & Bekas \\
\hline \multicolumn{7}{|c|}{ Street park } \\
\hline $\begin{array}{l}\text { Availability of street parks } \\
\text { [72] }\end{array}$ & $\mathrm{x}$ & $\mathrm{x}$ & $\mathrm{X}$ & $\mathrm{X}$ & $\mathrm{X}$ & $\mathrm{x}$ \\
\hline \multicolumn{7}{|c|}{ Trees } \\
\hline Position PI= & $\mathrm{PI}=1073.3$ & $\mathrm{PI}=446.1$ & $\mathrm{PI}=1573.4$ & $\mathrm{PI}=8685.5$ & $\mathrm{PI}=11334.4$ & $\mathrm{PI}=1661.8$ \\
\hline $\begin{array}{l}\qquad \sum_{1=1}^{K}(\mathrm{Ci}) / \sum_{i=1}^{K}(\mathrm{Ni}) \\
\mathrm{I}=1,2,3, \ldots \mathrm{k} \text { (Variation in } \\
\text { footpath width across various } \\
\text { parts of the street) }\end{array}$ & $\mathrm{x}$ & $\mathrm{x}$ & $\mathrm{x}$ & $\mathrm{x}$ & $\mathrm{x}$ & $\mathrm{x}$ \\
\hline
\end{tabular}




\begin{tabular}{|c|c|c|c|c|c|c|}
\hline $\begin{array}{l}\mathrm{Ci}=\text { Street length with the tree } \\
\text { in section } \mathrm{i} \text { - considered } \\
\text { standard limitation } * 9 \text { )/D } \\
\mathrm{D}>9 \\
\mathrm{C}=\text { Street length with the tree } \\
\text { in section } \mathrm{i} \text { - considered a } \\
\text { standard limitation } \\
\mathrm{D} \leq 9 \text { [29] }\end{array}$ & & & & & & \\
\hline $\begin{array}{l}\text { The branches of trees must } \\
\text { have at least } 2.4 \mathbf{~ m} \text { vertical } \\
\text { clearance [29] }\end{array}$ & $\mathrm{x}$ & $\mathrm{x}$ & $\mathrm{X}$ & $\mathrm{x}$ & $\mathrm{X}$ & $\mathrm{x}$ \\
\hline $\begin{array}{l}\text { Trees must be at least } 7.6 \mathbf{m} \\
\text { away from intersection [29] }\end{array}$ & $\mathrm{X}$ & $\mathrm{X}$ & $\mathrm{X}$ & $\mathrm{X}$ & $\mathrm{X}$ & $\mathrm{X}$ \\
\hline $\begin{array}{l}\text { Distance between trees }<=9 \mathrm{~m} \\
\text { to provide continuous canopy } \\
{[29]}\end{array}$ & $\mathrm{x}$ & $\mathrm{x}$ & $\mathrm{X}$ & $\mathrm{x}$ & $\mathrm{X}$ & $x$ \\
\hline $\begin{array}{l}\text { Trees must be planted on both } \\
\text { sides of the streets [29] }\end{array}$ & $\sqrt{ }$ & $\sqrt{ }$ & $\sqrt{ }$ & $\sqrt{ }$ & $\sqrt{ }$ & $\sqrt{ }$ \\
\hline & & & ash bin & & & \\
\hline Position $\mathrm{PI}=\mathrm{C} / \mathrm{N}$ & $\mathrm{PI}=0.5$ & $\mathrm{PI}=0$ & $\mathrm{PI}=0$ & $\mathrm{PI}=0$ & $\mathrm{PI}=0$ & $\mathrm{PI}=0$ \\
\hline $\begin{array}{l}\mathrm{C}=\text { Street length with standards } \\
\text { trash receptacle area+ their } \\
\text { support length }(\mathrm{m}) \\
\mathrm{N}=\text { Street length (both } \\
\text { sides)(m) [29] }\end{array}$ & $\mathrm{x}$ & $\mathrm{x}$ & $\mathrm{X}$ & $\mathrm{x}$ & $\mathrm{x}$ & $x$ \\
\hline $\begin{array}{l}\text { It should be } 9 \mathrm{~m} \text { far from } \\
\text { intersection [74] }\end{array}$ & $\mathrm{X}$ & $\mathrm{X}$ & $\mathrm{X}$ & $\mathrm{x}$ & $\mathrm{X}$ & $\mathrm{X}$ \\
\hline $\begin{array}{l}\text { A buffer of a } \min 0.6 \mathrm{~m} \text { from } \\
\text { the face of the curve should be } \\
\text { provided [29] }\end{array}$ & $\mathrm{X}$ & $\mathrm{x}$ & $\mathrm{X}$ & $\mathrm{X}$ & $\mathrm{X}$ & $\mathrm{X}$ \\
\hline $\begin{array}{l}\text { It should have min } 1.2 \mathrm{~m} \\
\text { clearance from bus stop } \\
\text { infrastructure [29] }\end{array}$ & $\mathrm{X}$ & $\mathrm{x}$ & $\mathrm{X}$ & $\mathrm{X}$ & $\mathrm{X}$ & $\mathrm{X}$ \\
\hline & & & laintenance & & & \\
\hline Pothole [70] & $\sqrt{ }$ & $\mathrm{X}$ & $\mathrm{X}$ & $\mathrm{X}$ & $\mathrm{X}$ & $\mathrm{X}$ \\
\hline Crack sealing [70] & $\mathrm{X}$ & $\mathrm{X}$ & $\mathrm{X}$ & $\mathrm{X}$ & $\mathrm{X}$ & $\mathrm{X}$ \\
\hline Curb repairs [70] & $\sqrt{ }$ & $\mathrm{X}$ & $\mathrm{X}$ & $\mathrm{X}$ & $\mathrm{X}$ & $\mathrm{X}$ \\
\hline Total & $\% 23$ & $\% 07$ & $\% 07$ & $\% 07$ & $\% 07$ & $\% 07$ \\
\hline
\end{tabular}




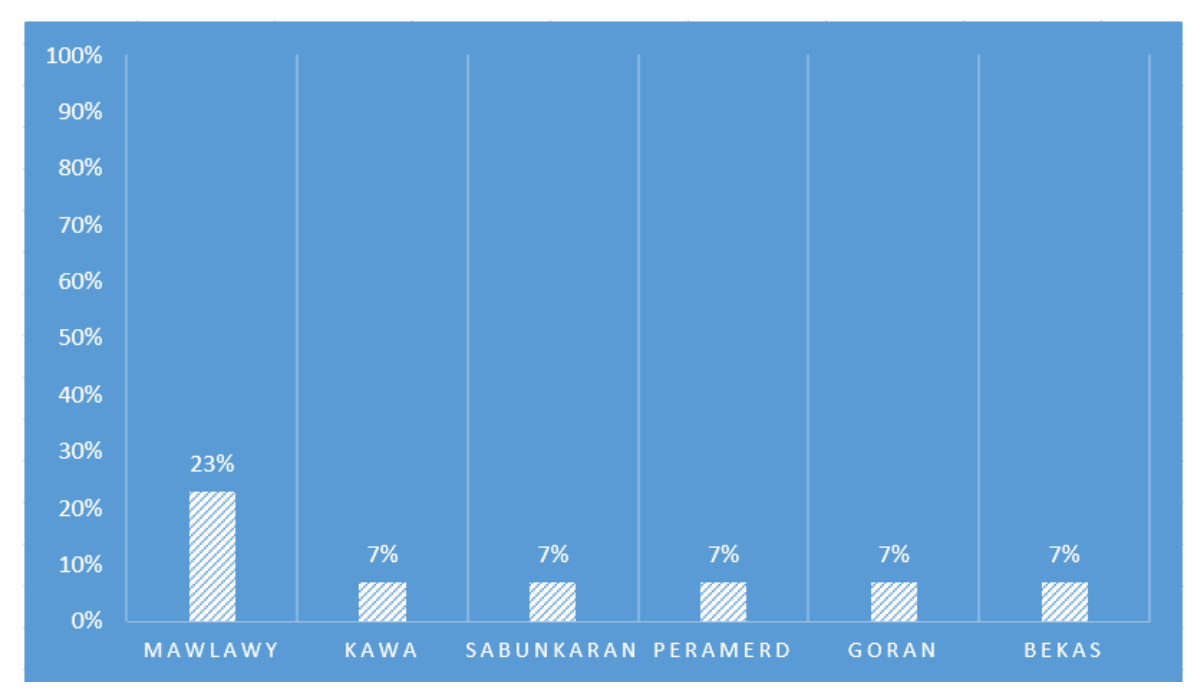

Figure 8 Aesthetic factor average performance comparison among the six streets (source: author).

\subsection{Destination factor}

Among the calculated and observed destination sub-factors, all the streets checked in only one sub-factor, availability of shops and restaurants (Table 7). This brings the street's overall performance in the destination factor to as low as 12\% (Figure 9). Despite this low standardbased destination performance for a street, these streets are famous for their vibrancy and pedestrian crowdedness is given their strategic location at the heart of the center of Sulaimani city and inclusion of various essential and non-essential shopping and other go-to services, including medical clinics.

Table 7: Destination sub factors calculation and comparison to standards (source: author).

\begin{tabular}{|c|c|c|c|c|c|c|}
\hline Sub factors & Mawlawy & Kawa & Sabunkaran & Peramerd & Goran & Bekas \\
\hline \multicolumn{7}{|c|}{ Shops and restaurants } \\
\hline $\begin{array}{l}\text { Availability of shops and } \\
\text { restaurants [29] }\end{array}$ & $\sqrt{ }$ & $\sqrt{ }$ & $\sqrt{ }$ & $\sqrt{ }$ & $\sqrt{ }$ & $\sqrt{ }$ \\
\hline \multicolumn{7}{|c|}{ Street park } \\
\hline $\begin{array}{l}\text { Availability of street parks } \\
\text { [73] }\end{array}$ & $\mathrm{X}$ & $\mathrm{X}$ & $\mathrm{x}$ & $\mathrm{x}$ & $\mathrm{X}$ & $\mathrm{X}$ \\
\hline \multicolumn{7}{|c|}{ Benches and seating areas } \\
\hline $\begin{array}{l}\text { Availability of benches and } \\
\text { seating areas [29] }\end{array}$ & $x$ & $\mathrm{x}$ & $\mathrm{x}$ & $\mathrm{x}$ & $\mathrm{x}$ & $\mathrm{x}$ \\
\hline \multicolumn{7}{|c|}{ Facilities } \\
\hline $\begin{array}{l}\text { Fire hydrant position } \mathrm{PI}= \\
\mathrm{C} / \mathrm{N} \\
\mathrm{C}=\text { No. of standard fire } \\
\text { hydrants } \\
\mathrm{N}=\text { total needed fire hydrants } \\
\text { in a street }[29]\end{array}$ & $\mathrm{PI}=0$ & $\begin{array}{r}\mathrm{PI}=0.09 \\
\mathrm{X}\end{array}$ & $\mathrm{PI}=0.4$ & $\begin{array}{r}\mathrm{PI}=0.001 \\
\mathrm{X}\end{array}$ & $\mathrm{PI}=0$ & $\mathrm{PI}=0$ \\
\hline $\begin{array}{l}\text { They need to be located in the } \\
\text { furnishing zone when the } \\
\text { zone is } 1.2 \mathbf{m} \text { or behind the } \\
\text { sidewalk with a min of } 1.8 \mathbf{m} \\
\text { clear for pedestrian zone [29] }\end{array}$ & $\mathrm{x}$ & $\mathrm{X}$ & $\mathrm{x}$ & $\mathrm{x}$ & $\mathrm{x}$ & $\mathrm{x}$ \\
\hline
\end{tabular}




\begin{tabular}{lcccc}
\hline $\begin{array}{l}\text { The distance from the nearest } \\
\text { fire hydrant to the front door } \\
\text { of a building should not } \\
\text { exceed 45m [29] }\end{array}$ & $\mathrm{X}$ & $\mathrm{X}$ & $\mathrm{X}$ & $\mathrm{X}$ \\
\hline $\begin{array}{l}\text { It should be 9m from } \\
\text { intersection [29] }\end{array}$ & $\mathrm{X}$ & $\mathrm{X}$ & $\mathrm{X}$ & $\mathrm{X}$ \\
\hline & \multicolumn{1}{c}{ Bike parking facilities } & $\mathrm{X}$ & $\mathrm{X}$ \\
\hline $\begin{array}{l}\text { Availability of bike parking } \\
\text { facilities [74] }\end{array}$ & $\mathrm{X}$ & $\mathrm{X}$ & $\mathrm{X}$ & $\mathrm{X}$ \\
\hline Total & $\% 12$ & $\% 12$ & $\% 12$ \\
\hline
\end{tabular}

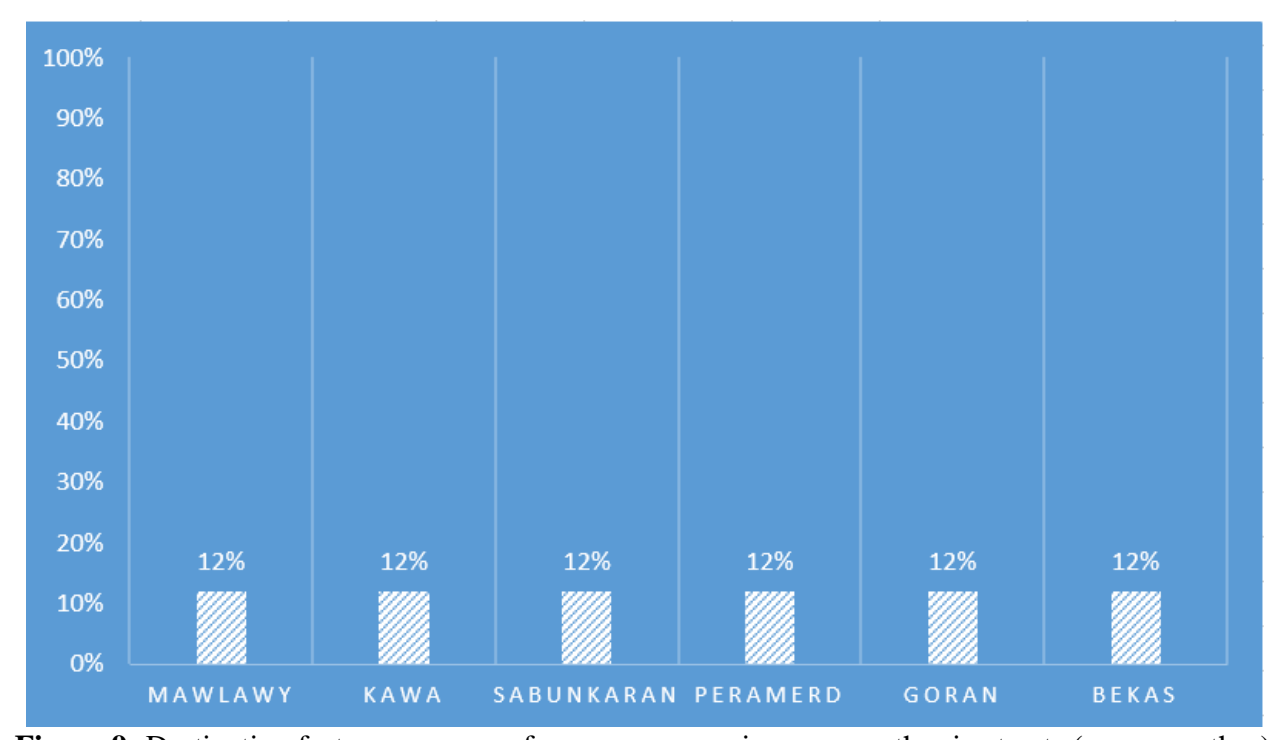

Figure 9: Destination factor average performance comparison among the six streets (source: author).

\subsection{Comfort factor}

As it appears in Table 8, the comfort sub factors performance among the six streets range between 27\% (Bekas street) and 45\% (in Mawlawy Street). Kawa, Sabunkaran, Peramerd, and Goran streets have the same performance score of $36 \%$ (Figure 10). Although all the streets perform less than $50 \%$ in the calculated and observed comfort sub-factors, in general, the streets have higher performance in comfort factor in comparison to the previous four factors of functional, safety, aesthetic, and destination.

Table 8: Comfort sub factors calculation and comparison to standards (source: author).

\begin{tabular}{|c|c|c|c|c|c|c|}
\hline Sub factors & Mawlawy & Kawa & Sabunkaran & Peramerd & Goran & Bekas \\
\hline \multicolumn{7}{|c|}{ Shops and restaurants } \\
\hline $\begin{array}{l}\text { Availability of shops and } \\
\text { restaurants [29] }\end{array}$ & $\sqrt{ }$ & $\sqrt{ }$ & $\sqrt{ }$ & $\sqrt{ }$ & $\sqrt{ }$ & $\sqrt{ }$ \\
\hline \multicolumn{7}{|c|}{ Shadows for pedestrian } \\
\hline $\begin{array}{l}\text { Availability of shadows for } \\
\text { pedestrian (over \% 50) [75] }\end{array}$ & $\sqrt{ }$ & $\sqrt{ }$ & $\sqrt{ }$ & $\sqrt{ }$ & $\sqrt{ }$ & $\sqrt{ }$ \\
\hline \multicolumn{7}{|c|}{ Path design } \\
\hline $\begin{array}{l}\mathrm{PI}=\sum_{i=1}^{K} \mathrm{DICix} L i \quad /(\text { Street length } \\
\text { (both sides)-Intersections length) }\end{array}$ & $\begin{array}{c}\mathrm{PI}=0.98 \leq \% 2 \\
\sqrt{ }\end{array}$ & $\begin{array}{c}\mathrm{PI}=1.44 \leq \% 2 \\
\sqrt{ }\end{array}$ & $\begin{array}{c}\mathrm{PI}=0.95 \leq \% 2 \\
\sqrt{ }\end{array}$ & $\begin{array}{c}\mathrm{PI}=1.12 \leq \% 2 \\
\sqrt{ }\end{array}$ & $\begin{array}{c}\mathrm{PI}=0.87 \leq \% 2 \\
\sqrt{ }\end{array}$ & $\begin{array}{c}\mathrm{PI}=33.66 \neq \% 2 \\
\mathrm{X}\end{array}$ \\
\hline
\end{tabular}


$\mathrm{i}=1,2,3, \ldots . ., \mathrm{k}$ (Variation in footpath width across various parts of the street)

$\mathrm{DIC}_{\mathrm{i}}=\mathrm{C}_{\mathrm{I}} / \mathrm{N}_{\mathrm{i}}$

$\mathrm{C}_{\mathrm{i}}=$ Sidewalk area with the

standard slope in section $\mathbf{i}\left(\mathrm{m}^{2}\right)$

$\mathrm{N}_{\mathrm{i}}=$ Street length (in section $\left.\mathrm{i}\right) * 1.5$

If $W<1.5 \mathrm{~m}$

$\mathbf{N}_{\mathrm{i}}=$ Street length (in section $\left.\mathrm{i}\right) * \mathbf{W}$

If $\mathrm{W}>=1.5 \mathrm{~m}$

$\mathbf{L}_{\mathrm{i}}=$ Street length (in section i) (m)

Sidewalk slope $\leq \% 2[68]$

\begin{tabular}{llllll}
\hline & Sidewalk height & & \\
\hline $\begin{array}{l}\text { Sidewalk height (0.20m) } \\
\text { Consistency [76] }\end{array}$ & $\mathrm{X}$ & $\mathrm{X}$ & $\mathrm{X}$ & $\mathrm{X}$ \\
\hline & Path width & & \\
\hline
\end{tabular}

$\mathrm{PI}=\sum_{i=1}^{K}(\mathrm{DICi}) \mathrm{PC}$ ix Li /Street

length (both sides)-Intersections length)*

$\mathrm{PI}=0.92$

$\mathrm{PI}=7.36$

ith

$i=1,2,3, \ldots k$ (Variation in footpath width across various parts of the street)

$\mathbf{P C i}=\mathrm{Ci} / \mathrm{Ni}$

$\mathrm{Ci}=$ Standard footpath area in section $\mathrm{i}\left(\mathbf{m}^{2}\right)$

$\mathrm{Ni}=$ Street length (in section $\mathrm{i}) * 1.5$

If $\mathrm{W}<\mathbf{1 . 5 0 m}$

$\mathrm{Ni}=$ Street length (in section $\mathrm{i}) * \mathrm{~W}$

If $\mathrm{W}>=1.50 \mathrm{~m}$

$\mathbf{L i}=$ Street length in section $\mathbf{i}(\mathrm{m})$

Minimum path width (PI) must be $1.5 \mathrm{~m}$ (recommended width 1.8 - 2.4 m)

*This equation was used since the path width changes in various parts of each of the six streets (see Figure 6) $[68]$

\section{Location of trees}

Position $\mathrm{PI}=$
$\mathbf{P} 1=\sum_{1=1}^{K}(\mathrm{Ci}) / \sum_{i=1}^{K}(\mathrm{Ni})$
$\mathrm{I}=1,2,3, \ldots \mathrm{k}($ Variation in footpath
width across various parts of the
street)
$\mathrm{Ci}=$ Street length with the tree in
section $\mathrm{i}$ - considered standard
limitation $* 9) / \mathrm{D}$
$\mathrm{D}>9$
$\mathrm{C}=$ Street length with the tree in
section i- considered a standard
limitation
$\mathrm{D}<=9$

$\mathrm{PI}=1073.3$

$\sqrt{ }$
$\mathrm{PI}=1573.4$
$\mathrm{X}$

$\mathrm{X}$
$\mathrm{PI}=1.12$

$\mathrm{PI}=0.87$

$\mathrm{PI}=33.66$ 


\begin{tabular}{|c|c|c|c|c|c|c|}
\hline \multicolumn{7}{|l|}{$\begin{array}{l}\text { Ni=(Street length (in section } \mathrm{i})- \\
\text { considered standard limitation } \\
\mathrm{P} 2=\mathrm{F} / \mathrm{N} \\
\text { The } \mathrm{F}=\mathrm{C} \text {-Street length that does } \\
\text { not have the first standard } \\
\text { condition } \\
\mathrm{N}=\text { Street length (both sides)-total } \\
\text { length of intersections and } \\
\text { considered standard limitation (m) } \\
\text { If } \mathrm{D} \text { varies in different parts of the } \\
\text { street } \\
\mathrm{P} 2=\sum_{1=1}^{K}(\mathrm{Ci}) / \sum_{i=1}^{K}(\mathrm{Ni}) \\
\mathrm{I}=1,2,3, \ldots \mathrm{k} \text { (Variation in footpath } \\
\text { width across various parts of the } \\
\text { street) [68] }\end{array}$} \\
\hline $\begin{array}{l}\text { Trees must be at least } 7.6 \mathrm{~m} \text { away } \\
\text { from intersection [29] }\end{array}$ & $\mathrm{x}$ & $\mathrm{x}$ & $\mathrm{x}$ & $x$ & $\mathrm{x}$ & $\mathrm{X}$ \\
\hline $\begin{array}{l}\text { Distance between trees }<=9 \mathrm{~m} \text { to } \\
\text { provide continuous canopy [29] }\end{array}$ & $\mathrm{x}$ & $\mathrm{X}$ & $x$ & $\mathrm{x}$ & $\mathrm{x}$ & $\mathrm{x}$ \\
\hline $\begin{array}{l}\text { Trees must be planted on both } \\
\text { sides of the streets [29] }\end{array}$ & $\sqrt{ }$ & $\sqrt{ }$ & $\sqrt{ }$ & $\sqrt{ }$ & $\sqrt{ }$ & $\sqrt{ }$ \\
\hline \multicolumn{7}{|c|}{ Location of lighting } \\
\hline $\begin{array}{l}\text { The lighting poles should be } \\
\text { maximum 9m apart [29] }\end{array}$ & $\mathrm{X}$ & $\mathrm{X}$ & $\mathrm{X}$ & $\mathrm{X}$ & $\mathrm{X}$ & $\mathrm{X}$ \\
\hline \multicolumn{7}{|c|}{ Benches and seating areas } \\
\hline $\begin{array}{l}\text { Availability of benches and seating } \\
\text { areas [29] }\end{array}$ & $\mathrm{x}$ & $\mathrm{x}$ & $\mathrm{x}$ & $\mathrm{x}$ & $x$ & $\mathrm{x}$ \\
\hline Total & $\% 45$ & $\% 36$ & $\% 36$ & $\% 36$ & $\% 36$ & $\% 27$ \\
\hline
\end{tabular}

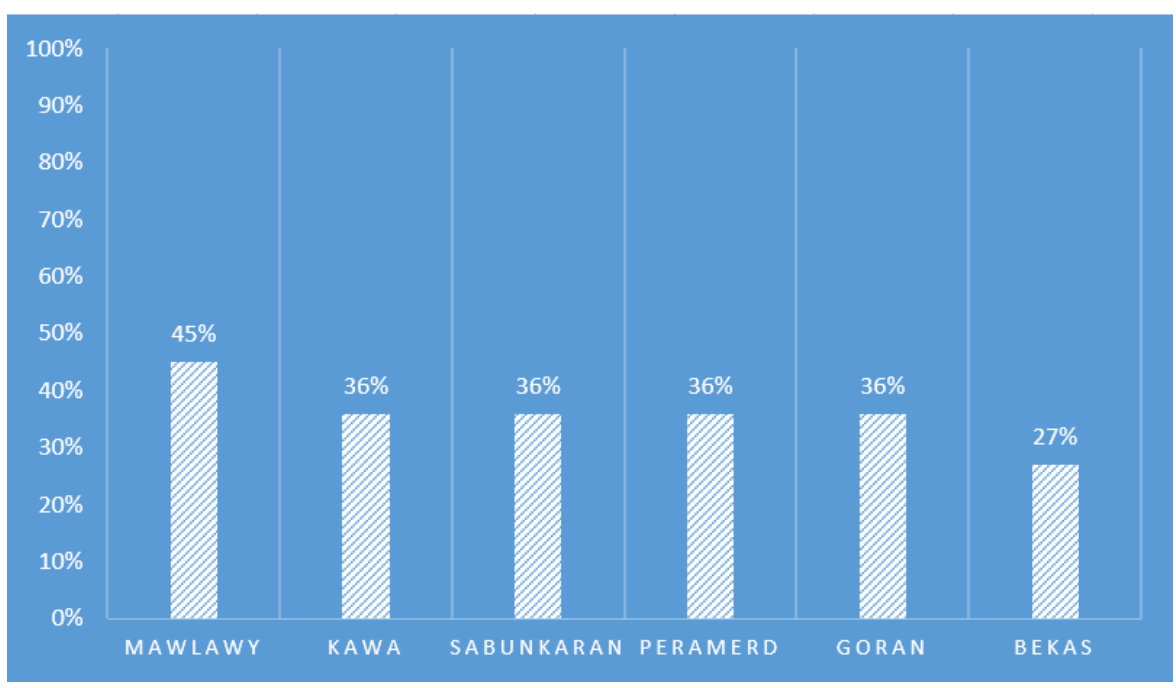

Figure 10: Comfort factor average performance comparison among the six streets (source: author).

Overall and as summarized in Table 9, Mawlawy Street performs higher in all five factors than the other five streets in the center of Sulaimani city. In the $2^{\text {nd }}$ place comes the performance of Sabunkaran, Peramerd, and Goran streets, followed by the performance of Kawa Street. Bekas street has the lowest performance among the six city center streets. 
Table 9: Summary of the six street performance across the five factors (source: author).

\begin{tabular}{lcccccc}
\hline \multicolumn{1}{c}{ Factors/streets } & Mawlawy\% & Kawa\% & Sabunkaran\% & Peramerd\% & Goran\% & Bekas\% \\
\hline Functional & 60 & 17 & 21 & 21 & 0 & 13 \\
\hline Safety & 57 & 0 & 0 & 7 & 12 & 7 \\
\hline Aesthetic & 23 & 7 & 12 & 36 & 36 & 7 \\
\hline Destination & 12 & 12 & 36 & 27 \\
\hline Comfort & 45 & 36 & 72 & 0 \\
\hline
\end{tabular}

\section{CONCLUSION AND FUTURE WORK}

Walkability is an important element of any built environment. A mounting body of research provides evidence about its environmental, economic, social, and health benefits. Attractive and livable cities with vibrant city centers offer a high degree of walkability. Since walkability within cities often does not happen by accident, comprehensive walkability and walking supportive planning policies and guidelines are required with the support of proper implementation and enforcement. Informed planning policies and guidelines require accurate data collection and continuous evaluation.

The unsustainable transformation of the city center of Sulaimani is making this historic center and its vibrant streets into high congestion streets with consequences on their social and cultural characters in the long-term. Absence of walkability supportive planning guidelines and policies as well as walkability related data and evaluations are further deteriorating the state of walkability in the city center streets.

This study systematically measured, quantified, and evaluated the state of walkability in the six major connected streets in Sulaimani city center through analyzing their physical feature measurement and observations across five main walkability factors (functional, safety, aesthetic, destination, and comfort) from the literature. Findings from the paper show various levels of (high to low) differences in the state of walkability among the streets and that they overwhelmingly fall below standards in the factors across the vast majority of the streets. Even the highest performing street among the six streets (Mawlawy) performs less than $50 \%$ in three out of the five factors. The performance inconsistency and low score across the streets indicate a lack of walkability supportive guidelines, policies, and enforcement. This conclusion is verified by discussions with decision-makers in the related municipality in the city. Improving the state of walkability in those and other streets in the city will, therefore, require comprehensive long-term walkability supportive policies, regulations, and guidelines that are supported with proper implementation, enforcement, and monitoring. Little can be achieved and/or sustained without such higher-level intervention.

In the next part of the study, we evaluate the state of walkability in the same streets across the five factors, but this time from the pedestrian's experience and perspective. We will then compare the performance results to those from the physical measurement. This will help with further understanding the walkability performance of the streets and any interplay between the physical features and pedestrian perception on the state of walkability and walkability evaluation in those streets. 


\section{Reference}

[1] J. Jacobs, "Pedestrian Cities / Quality of Life," 2000. http://www.newurbanism.org/pedestrian.html (accessed Jun. 01, 2020).

[2] E. I. Unit, “A summary of the Liveability Ranking and Overview," Retrieved Sept., vol. 13, p. $2011,2011$.

[3] N. Pasaogullari and N. Doratli, "Measuring accessibility and utilization of public spaces in Famagusta," Cities, vol. 21, no. 3, pp. 225-232, 2004.

[4] S. Shamsuddin, N. R. A. Hassan, and S. F. I. Bilyamin, "Walkable environment in increasing the liveability of a city," Procedia-Social Behav. Sci., vol. 50, pp. 167-178, 2012.

[5] S. F. Wong, "Walkability and community identity in the city centre of Kuala Lumpur," 2011.

[6] S. Abley, "Walkability scoping paper," Retrieved March, vol. 4, p. 2011, 2005.

[7] P. Cambra, "Pedestrian accessibility and attractiveness indicators for walkability assessment," Lisbon Dep. Civ. Eng. Archit. Inst. Super. Técnico, Univ. Técnica Lisboa, 2012.

[8] R. H. Lo, "Walkability: what is it?," J. Urban., vol. 2, no. 2, pp. 145-166, 2009.

[9] A. Forsyth, "What is a walkable place? The walkability debate in urban design," Urban Des. Int., vol. 20, no. 4, pp. 274-292, 2015.

[10] Z. Asadi-Shekari, M. Moeinaddini, and M. Zaly Shah, "Non-motorised level of service: Addressing challenges in pedestrian and bicycle level of service," Transp. Rev., vol. 33, no. 2, pp. 166-194, 2013.

[11] J. Oliver-Solà, A. Josa, J. Rieradevall, and X. Gabarrell, "Environmental optimization of concrete sidewalks in urban areas," Int. J. Life Cycle Assess., vol. 14, no. 4, pp. 302-312, 2009.

[12] B. W. Landis, V. R. Vattikuti, R. M. Ottenberg, D. S. McLeod, and M. Guttenplan, "Modeling the roadside walking environment: pedestrian level of service," Transp. Res. Rec., vol. 1773, no. 1, pp. 82-88, 2001.

[13] P. K. Maghelal and C. J. Capp, "Walkability: A Review of Existing Pedestrian Indices.," J. Urban Reg. Inf. Syst. Assoc., vol. 23, no. 2, 2011.

[14] N. Gallin, "Quantifying pedestrian friendliness--guidelines for assessing pedestrian level of service," Road Transp. Res., vol. 10, no. 1, p. 47, 2001.

[15] J. Y. S. Lee and W. H. K. Lam, "Levels of service for stairway in Hong Kong underground stations," $J$. Transp. Eng., vol. 129, no. 2, pp. 196-202, 2003.

[16] L. B. Dixon, "Bicycle and pedestrian level-of-service performance measures and standards for congestion management systems," Transp. Res. Rec., vol. 1538, no. 1, pp. 1-9, 1996.

[17] H. V. Krambeck, "The global walkability index," Massachusetts Institute of Technology, 2006.

[18] S. U. Jensen, "Pedestrian and bicyclist level of service on roadway segments," Transp. Res. Rec., vol. 2031, no. 1 , pp. 43-51, 2007.

[19] H. L. Le Grand, "Pickup and dump street sweeper." Google Patents, Jul. 27, 1954.

[20] G. Evans, "Creative cities, creative spaces and urban policy," Urban Stud., vol. 46, no. 5-6, pp. 1003-1040, 2009.

[21] A. Forsyth and M. Southworth, "Cities afoot-Pedestrians, walkability and urban design." Taylor \& Francis, 2008.

[22] T. A. Litman, "Economic value of walkability," Transp. Res. Rec., vol. 1828, no. 1, pp. 3-11, 2003.

[23] R. E. Killingsworth and J. Lamming, "Development and public health," Urban L., vol. 60, no. 7, pp. 12-16, 2001.

[24] X. Li, "Study of Environmental Variables Affecting Walkability: Learning From Main Street in Downtown Fort Worth," 2015.

[25] M. Jamal, W. Khasraw, S. Khabat, and R. K. Mohammed-Amin, "Investigating and boosting walkability in Sulaimani's mixed-use streets: Jamal Irfan street as a case study,” Kurdistan J. Appl. Res., vol. 2, no. 3, pp. 397-409, 2017

[26] P. N. Seneviratne and J. F. Morrall, "Level of service on pedestrian facilities," Transp. Q., vol. 39, no. 1, pp. $109-123,1985$

[27] N. T. Coffee, N. Howard, C. Paquet, G. Hugo, and M. Daniel, "Is walkability associated with a lower cardiometabolic risk?," Health Place, vol. 21, pp. 163-169, 2013.

[28] V. Zvonarev et al., "Neurocognitive Performance of African Americans and Hispanic Adults in Relation to Diet and Physical Activity: A Literature Review," J. Neurol. Res., 2020.

[29] S. Park, "Defining, measuring, and evaluating path walkability, and testing its impacts on transit users' mode choice and walking distance to the station," 2008

[30] B. Catalán, D. Saurí, and P. Serra, "Urban sprawl in the Mediterranean?: Patterns of growth and change in the Barcelona Metropolitan Region 1993-2000,” Landsc. Urban Plan., vol. 85, no. 3-4, pp. 174-184, 2008.

[31] J. Emery and C. Crump, "The WABSA project: assessing and improving your community's walkability \& bikeability. 2003," North Carolina Dep. Heal. Behav. Heal. Educ. Sch. Public Heal. Univ. North Carolina Chapel Hill, 2011

[32] J. I. Gilderbloom, W. W. Riggs, and W. L. Meares, "Does walkability matter? An examination of walkability's impact on housing values, foreclosures and crime," Cities, vol. 42, pp. 13-24, 2015.

[33] J. Foord, "Mixed-use trade-offs: how to live and work in a compact city neighbourhood," Built Environ., vol 36 , no. 1 , pp. 47-62, 2010.

[34] W. Zhugen, Q. Stevens, and H. Shuyue, "Walkable City Collaborative Planning Strategy: The Case Study of Melbourne," Urban Dev. Stud., vol. 25, no. 1, pp. 77-86, 2018.

[35] N. N. J. Foran, "Bay Area Walk score premiums: unlocking value through neighborhood trends," Massachusetts Institute of Technology, 2017 
[36] R. M. Kavoussi, "Export expansion and economic growth: Further empirical evidence,” J. Dev. Econ., vol. 14, no. 1, pp. 241-250, 1984.

[37] G. Knaap and E. Talen, "New urbanism and smart growth: A few words from the academy," Int. Reg. Sci. Rev., vol. 28, no. 2, pp. 107-118, 2005.

[38] L. Dörrzapf, A. Kovács-Györi, B. Resch, and P. Zeile, "Defining and assessing walkability: a concept for an integrated approach using surveys, biosensors and geospatial analysis," Urban Dev. issues, vol. 62, no. 1, pp. 5-15, 2019.

[39] Y. Llewelyn-Davies, "Urban design compendium,” English Partnerships, London, 2000.

[40] N. H. A. Aown, "Development of planning and design standards for sidewalks: The role of municipal to provide safe and comfortable environment for users of sidewalks in the city of Baghdad," in 20181 st International Scientific Conference of Engineering Sciences-3rd Scientific Conference of Engineering Science (ISCES), 2018, pp. 237-242.

[41] M. Biddulph, "Street design and street use: comparing traffic calmed and home zone streets," J. Urban Des., vol. 17 , no. 2 , pp. 213-232, 2012.

[42] H. C. Manual, "Highway capacity manual," Washington, DC, vol. 2, 2000.

[43] L. D. Frank, T. L. Schmid, J. F. Sallis, J. Chapman, and B. E. Saelens, "Linking objectively measured physical activity with objectively measured urban form: findings from SMARTRAQ," Am. J. Prev. Med., vol. 28, no. 2, pp. 117-125, 2005.

[44] S. Abley and S. Turner, "Predicting walkability: technical report," New Zeal. Transp. Agency, 2011.

[45] C. Henson, "Levels of service for pedestrians," ITE J., vol. 70, no. 9, pp. 26-30, 2000

[46] K. K. Finnis and D. Walton, "Field observations to determine the influence of population size, location and individual factors on pedestrian walking speeds," Ergonomics, vol. 51, no. 6, pp. 827-842, 2008.

[47] S. Sarkar, "Qualitative evaluation of comfort needs in urban walkways in major activity centers," Transp. Q., vol. 57, no. 4, pp. 39-59, 2003.

[48] R. Ewing, Traffic Calming: State of the Practice, ITE/FHWA, August 1999, no. FHWA-RD-99-135. United States. Federal Highway Administration, 1999.

[49] T. A. N. Dandan, W. Wei, L. U. Jian, and B. Yang, "Research on methods of assessing pedestrian level of service for sidewalk," J. Transp. Syst. Eng. Inf. Technol., vol. 7, no. 5, pp. 74-79, 2007.

[50] D. Mozer, "Calculating multi-mode levels-of-service," Int. Bicycl. Fund, 1994.

[51] R. Cervero and K. Kockelman, "Travel demand and the 3Ds: Density, diversity, and design," Transp. Res. Part D, Transp. Environ., vol. 2, no. 3, pp. 199-219, 1997.

[52] B. J. Lee, T. Y. Jang, W. Wang, and M. Namgung, "Design criteria for an urban sidewalk landscape considering emotional perception," J. urban Plan. Dev., vol. 135, no. 4, pp. 133-140, 2009.

[53] Z. Asadi-Shekari, M. Moeinaddini, and M. Zaly Shah, "Disabled pedestrian level of service method for evaluating and promoting inclusive walking facilities on urban streets," J. Transp. Eng., vol. 139, no. 2, pp. 181-192, 2013.

[54] D. Neyland, Privacy, surveillance and public trust. Springer, 2006.

[55] S. L. Handy, M. G. Boarnet, R. Ewing, and R. E. Killingsworth, "How the built environment affects physical activity: views from urban planning," Am. J. Prev. Med., vol. 23, no. 2, pp. 64-73, 2002.

[56] L. D. Frank, "Land use and transportation interaction: implications on public health and quality of life," $J$. Plan. Educ. Res., vol. 20, no. 1, pp. 6-22, 2000.

[57] D. C. Shoup, “Cruising for parking," Transp. Policy, vol. 13, no. 6, pp. 479-486, 2006.

[58] V. Mukhija and D. Shoup, "Quantity versus quality in off-street parking requirements," J. Am. Plan. Assoc., vol. 72, no. 3, pp. 296-308, 2006.

[59] A. P. Chrest, M. S. Smith, S. Bhuyan, M. Iqbal, and D. R. Monahan, Parking structures: planning, design, construction, maintenance and repair. Springer Science \& Business Media, 2012.

[60] M. S. Smith, Crime prevention through environmental design in parking facilities. US Department of Justice, Office of Justice Programs, National Institute of ..., 1996.

[61] J. D. Sartor and G. B. Boyd, Water pollution aspects of street surface contaminants, vol. 81. US Government Printing Office, 1972.

[62] R. A. Weant and H. S. Levinson, "Parking," 1990.

[63] City Population, "Iraq population,” 2018. http://www.citypopulation.de (accessed Jun. 01, 2020).

[64] T. C. Z. A. Project, “Bestansur,” 2012. https://www.google.com/search (accessed Jun. 01, 2012).

[65] R. K. Mohammed-Amin and A. F. Ali, "The Case of Restoring Sarai building as a Museum. The International Journal of the Inclusive Museum," vol. 13, no. 02, pp. 1-20, 2020, doi: 10.18848/1835-2014/CGP.

[66] R. A. Hasan, A. H. Abbas, K. M. Kwayu, and J.-S. Oh, "Role of social dimensions on active transportation and environmental protection: A survey at the University of Samarra, Iraq," J. Transp. Heal., vol. 14, p. 100564, 2019

[67] Kurdipedia, "Kurdipedia.org," 2020. https://www.kurdipedia.org/library.aspx?lng=1 (accessed Jun. 01, 2020).

[68] Z. Asadi-Shekari, M. Moeinaddini, and M. Z. Shah, "A pedestrian level of service method for evaluating and promoting walking facilities on campus streets," Land use policy, vol. 38, pp. 175-193, 2014

[69] Z. Asadi-Shekari, M. Moeinaddini, and M. Z. Shah, "Pedestrian safety index for evaluating street facilities in urban areas," Saf. Sci., vol. 74, pp. 1-14, 2015.

[70] K. C. W. Plan, "Measuring walkability: Tools and assessment." 2014.

[71] T. Pikora, B. Giles-Corti, F. Bull, K. Jamrozik, and R. Donovan, "Developing a framework for assessment of the environmental determinants of walking and cycling," Soc. Sci. Med., vol. 56, no. 8, pp. 1693-1703, 2003.

[72] Y. Qiu, X. Liang, and Z. Dai, "Backstepping dynamic surface control for an anti-skid braking system," 
Control Eng. Pract., vol. 42, pp. 140-152, 2015.

[73] D. Burden, M. Wallwork, K. Sides, R. Trias, and H. Rue, Street design guidelines for healthy neighborhoods. Center for Livable Communities Sacramento, Calif, 1999.

[74] V. Mehta, The street: a quintessential social public space. Routledge, 2013.

[75] T. K. Chow, S. W. Corbett, and D. J. Farstad, "Do conventional bicycle helmets provide adequate protection in mountain biking?," Wilderness Environ. Med., vol. 6, no. 4, pp. 385-390, 1995

[76] H. T. Nguyen and B. Bhanu, "Real-time pedestrian tracking with bacterial foraging optimization," in 2012 IEEE Ninth International Conference on Advanced Video and Signal-Based Surveillance, 2012, pp. 37-42. 